\title{
Designing indicators for assessing the effects of marine protected areas on coral reef ecosystems: A multidisciplinary standpoint
}

\author{
Dominique Pelletier ${ }^{1, a}$, Jose A. García-Charton ${ }^{2}$, Jocelyne Ferraris ${ }^{3}$, Gilbert David ${ }^{4}$, Olivier Thébaud ${ }^{5}$, \\ Yves Letourneur $^{6}$, Joachim Claudet ${ }^{1,7}$, Marion Amand ${ }^{1,8}$, Michel Kulbicki ${ }^{3,8}$ and René Galzin ${ }^{7}$ \\ 1 IFREMER, Laboratoire MAERHA (Mathématiques Appliquées à l'Exploitation des Ressources halieutiques), BP 21105, \\ 44311 Nantes Cedex 03, France \\ 2 Universidad de Murcia, Departamento de Ecología e Hidrología, Campus de Espinardo, 30100 Murcia, Spain \\ 3 IRD-UR CoRéUs, Université de Perpignan, 52 avenue Paul Alduy, 66860 Perpignan, France \\ ${ }^{4}$ IRD-US Espace, BP 172, 97492 Ste Clotilde, La Réunion \\ 5 IFREMER Centre de Brest, Service d'Economie maritime, BP 70, 29280 Plouzané, France \\ 6 Université de la Méditerranée, Centre d'Océanologie de Marseille, UMR 6540 Dimar, Campus de Luminy, Case 901, \\ 13288 Marseille Cedex 9, France \\ 7 EPHE UMR 8046 CNRS, 52 avenue Paul Alduy, 66860 Perpignan Cedex, France \\ ${ }^{8}$ IRD Centre de Nouméa, Unité de Recherche CoRéUs, BP A5, 98848 Nouméa Cedex, Nouvelle-Calédonie
}

Received 24 February 2004; Accepted 18 September 2004

\begin{abstract}
The present paper aims at identifying and assessing indicators of the effects of Marine Protected Areas (MPAs) in coral reef regions, based on a bibliography review in ecology, economics and social sciences. First the various effects studied within each of these domains and the variables used to measure them were censused. Potential ecological indicators were assessed through their link with the question used (here termed "relevance") and their "effectiveness" which encompasses the issues of precision, accuracy and statistical power. Relevance and effectiveness were respectively measured by the frequency of use of each indicator and the proportion of significant results in the reviewed articles. For social and economic effects, the approach was not possible due to the low number of references; we thus discussed the issue of finding appropriate indicators for those fields. Results indicate: 1- the unbalance in literature between disciplines; 2- the need for protocols and methodologies which include controls in order to assess MPA effects; 3- an important proportion of ecological indicators with low effectiveness; 4- the large number of ecological effects still not studied or not demonstrated at present.
\end{abstract}

Key words: Marine Protected Areas / Ecological, economic and social indicators / Pluridisciplinary / Coral reef ecosystems / Coastal management

Résumé - Quels indicateurs pour évaluer les effets des aires marines protégées sur les écosystèmes coralliens ? Un point de vue pluridisciplinaire. Cet article vise à identifier des indicateurs de l'effet des aires marines protégées (AMP) en milieu corallien, sur la base d'une synthèse bibliographique dans les domaines écologiques, économiques et sociaux, et principalement en milieu corallien. Nous recensons d'abord les différents effets attendus des AMP pour chacun des domaines, et les variables retenues pour les étudier. Les indicateurs écologiques potentiels sont évalués au travers de leur lien avec l'effet étudié (ici appelé "pertinence») et de leur «efficacité » qui regroupe les notions de précision, justesse et puissance statistique. Pertinence et efficacité sont respectivement mesurées par la fréquence d'utilisation et la proportion de résultats significatifs trouvés dans les articles recensés. Pour les aspects économiques et sociaux, le faible nombre de références ne permet pas une approche comparable à celle utilisée pour les indicateurs écologiques, et nous discutons donc de la question de l'identification d'indicateurs, et suggérons quelques pistes de recherche. Les principales conclusions de ce travail sont : i) le décalage entre les nombres de publications entre disciplines; ii) la nécessité de protocoles et méthodologies incluant des situations de contrôle pour évaluer les effets des MPA; iii) la faible efficacité de nombreux indicateurs écologiques; et iv) le nombre élevé d'effets peu ou pas étudiés ou démontrés à l'heure actuelle.

a Corresponding author: dpellet@ifremer.fr 


\section{Introduction}

Coral reefs are an outstanding feature of shallow marine areas in tropical regions of the world. They are home to more than one quarter of all known marine fish species (McAllister 1988; Sale 2002; Moberg and Rönnback 2003). Estimates of the seafood productivity of properly managed reefs range from 15 (Bryant et al. 1998) to $35 \mathrm{t} \mathrm{km}^{-2} \mathrm{y}^{-1}$ (Russ 1991). Coral reefs host ecosystems that represent a small fraction of the world's commercial fish yield (about 10\% of global catches in volume according to FAO figures of 1989), but support subsistence and local economy needs in many developing countries (Medley et al. 1993). Coral reefs have been estimated to provide each year roughly $€ 30$ billion in net benefits in goods and services to world economies, including tourism, fisheries and coastal protection (Cesar et al. 2003). Marine Protected Areas and in particular no-take marine reserves have long been envisaged as a way to protect coral reef ecosystems and associated fisheries, because they were thought more practical than other forms of fishery management (Roberts and Polunin 1991).

The term "Marine Protected Area (MPA)" is defined here in the classical sense of "any area of intertidal or subtidal terrain, together with its overlying water and associated flora, fauna, historical and cultural features, which has been reserved by law or other effective means to protect part or all of the enclosed environment" (Kelleher and Kenchington 1992), corresponding to resolution 17.38 of the 1988 World Conservation Union (IUCN) General Assembly. In the literature, the terms marine reserve, marine protected area, no-take zone, harvest refugia, sanctuary are often used for areas where fishing is totally prohibited (but see Agardy et al. 2003 for a presentation of the terms in use). In this article, we used the term marine reserve for this kind of area, and the term MPA in the wider sense defined hereabove. However, we do not consider customary marine tenures as described in Ruddle (1989) and Ruddle and Johannes (1990), i.e. Traditional Territorial Use Rights for Fishing (TURF).

MPAs are recent compared to terrestrial protected areas. There were 118 marine protected areas in 1970, 319 by 1980 (Silva et al. 1986; Kelleher and Kenchington 1992), and by 1995, their total number exceeded 1300 (Kelleher et al. 1995). This dynamics was spurred in part by international conventions and organisations such as the World Conservation Union (IUCN), which created specific programs for promoting a worldwide system of MPA, with the main objective "to provide for the protection, restoration, wise use, understanding and enjoyment of the marine heritage of the world in perpetuity through the creation of a global, representative system of MPAs and through the management in accordance with the principles of the world conservation strategy of human activities that use or affect the marine environment" (Kelleher and Kenchington 1992). Most MPAs located in developing countries were created under the impetus of international organisations (like United Nations Educational Scientific and Cultural Organization (UNESCO), United Nations Environmental Program (UNEP), United Nations Development Program (UNDP), IUCN, World Wide Fund for Nature or World Bank), national NGOs or private donors. Out of the 1300 MPA recognised by $\mathrm{IUCN}^{1}, 400$ have been established in coral reefs (Salvat et al. 2002), mostly in the last two decades. Concomitantly, MPA have been more and more studied as a "new" tool for marine ecosystem conservation and fisheries management, giving rise to many scientific publications, and a number of international conferences, workshops and research projects (Dugan and Davis 1993; Yoklavitch 1998; Conover et al. 2000; Polunin 2000; Kruse et al. 2001; Sumaïla and Alder 2001; National Research Council 2001).

Although there are a number of studies aimed at assessing MPA-related effects, more insight is needed into the question of assessing the ability of MPAs to achieve the management objectives initially stated, taking into account managers' expectations, monitoring needs and constraints. This implies looking at the indicators that are appropriate for assessing the effects of MPAs on ecosystems, resources and human activities. An indicator may be seen as a qualitative or quantitative variable that can be obtained from field surveys or from models, and that can be directly linked to a management objective or a research question (see Ferraris et al. 2005 for references). These authors proposed two main desirable features for a good indicator: i) the relevance to the assessment of interest, i.e. the link with the assessment objective; and ii) the effectiveness, i.e. the reliability in terms of precision, accuracy of the indicator and risk of making a wrong assessment. Selecting appropriate indicators for the assessment of MPA effects thus implies to first identify the objectives that prevail in MPA establishment.

The aim of the article is to identify and characterise the indicators used for assessing the effects of MPAs on coral reef ecosystems, and their associated economic and social consequences, taking the general objectives of MPA creation into account. We focus on quantitative indicators, although we acknowledge the existence of qualitative approaches, that may sometimes be more suitable in data-poor situations or in the case of social studies. Consistently with the definition of indicators proposed above, we make a distinction between the effects of MPAs that need to be estimated, the variables or indices used to measure these effects, and the criteria which can be used to assess the performance of these variables as indicators.

We examined the existing literature to list the ecological, economic and social effects that can be expected from the implementation of an MPA. For each of the effects identified, we listed the variables that were used in published empirical studies. For ecological effects, the relevance and effectiveness of each potential indicator were assessed using scores based on the bibliography analysis. For economic and social effects, we critically discussed the possibility of defining indicators from existing literature.

\section{Management objectives}

At the 1992 Congress of the World Commission on Protected Areas $^{2}$ (WCPA), a total of six categories of protected

\footnotetext{
1 United Nations list of National Parks and Equivalent Reserves, 1997 edition.

2 Includes all protected areas, both terrestrial and marine.
} 
Table 1. Management objectives for marine protected areas (MPA), as listed from the literature. Objectives linked to resolution of conflicts between different users groups were not reported.

\begin{tabular}{|l|l|l|l|l|}
\hline Domain & $\begin{array}{l}\text { Conservation Heritage } \\
\text { preservation }\end{array}$ & Knowledge & Fishing & Other uses \\
\hline Objectives & $\begin{array}{l}\text { Conservation } \\
\text { Habitat protection } \\
\text { Protection of emblematic species } \\
\text { Heritage preservation }\end{array}$ & $\begin{array}{l}\text { Education } \\
\text { Research }\end{array}$ & $\begin{array}{l}\text { Protection of resources } \\
\text { Nursery protection } \\
\text { Sustainable exploitation } \\
\text { Rehabilitation of resources }\end{array}$ & $\begin{array}{l}\text { Promotion of tourism and } \\
\text { recreational activities (e.g. } \\
\text { diving) }\end{array}$ \\
\hline
\end{tabular}

areas reflecting different management regimes and objectives were agreed upon: 1) strict nature reserve/wilderness area; 2) national park; 3) natural monument; 4) habitat/species management area; 5) protected landscape/seascape; 6) management resource protected area. This classification was endorsed at the IUCN general assembly in 1994 (David 1998). Salm et al. (2000) see two main motivations for MPAs: ensuring sustainability of economic resources, and protection of species, biodiversity and landscapes. In a review of 30 articles, Boersma and Parrish (1999) listed more precisely the objectives of establishing marine reserves: protection of local marine resources $(93 \%)$, promotion or control of tourism $(67 \%)$, protection of biodiversity (67\%), and enhancement of fisheries through protection or management $(53 \%)$. In the present review, we summarized management objectives from existing literature into four domains: conservation, knowledge, fisheries and other uses (Table 1).

In addition to these objectives, managers also view MPA as a mean to control access to coastal areas for resolving present or anticipated conflicts between coastal area users (Agardy 2000; Claudet and Pelletier 2004). A potential objective of MPAs may be to strengthen property and liability rights to the protected ecosystems, thereby ensuring their more efficient use and protection (Hoagland et al. 1995). This standpoint has however been challenged by Crosby et al. (2002), who pointed out that limiting access to marine resources for some user groups, in particular fishermen, may disrupt the socio-economic stability of coastal communities and result in conflicts among user groups competing for the same limited resources.

\section{Effects of MPA establishment: Expectations and observations}

In this section, we reviewed the main effects expected from the establishment of an MPA. We examined articles studying the impact of MPAs from ecological, economic and social standpoints. Although the review focused on coral reef ecosystems, we also included a number of studies pertaining to other ecosystems. A distinction was made between effects pertaining to marine populations and ecosystems (referred to as "Ecological effects"), and effects pertaining to economic and social aspects. The literature search focused on primary journals. For ecological effects, the search was restricted to empirical studies concerning existing MPAs, i.e. 94 references. In the case of economic effects, both modelling and empirical studies were considered, which amounted to 32 references. In the case of social effects, we excluded papers that were purely descriptive accounts and too qualitative to allow for subsequent indicator definition. Under these conditions, only $10 \mathrm{ac}-$ cessible references could be found. In each domain, references were classified according to the effects studied, and the variables observed and/or analysed were reported.

\subsection{Ecological effects}

More than 20 expected effects were listed from articles including a bibliography review (Plan Development Team 1990; Roberts and Polunin 1991, 1993; Jones et al. 1992; Dugan and Davis 1993; Rowley 1994; Bohnsack 1996; Allison et al. 1998; Lauck et al. 1998; García-Charton and Pérez-Ruzafa 1999; Crowder et al. 2000; García-Charton et al. 2000; Pinnegar et al. 2000; Planes et al. 2000; Roberts and Hawkins 2000; Russ 2002; Sànchez-Lizaso et al. 2000; Halpern 2003).These articles generally distinguish effects expected inside and outside the protected areas. Effects of MPA on the environment and ecosystem surrounding the MPA are tied to spillover, i.e. emigration and/or dispersion of recruited stages and exportation of eggs and larvae, the MPA acting as a biomass reservoir, if possible enhancing fisheries yields. Some of the listed effects within MPA may appear redundant since they were formulated in different ways by authors. In the present article, effects were classified as: i) effects at population level (Table 2); ii) effects at community level (Table 3 ); iii) habitat-related effects (Table 4). Note that expected effects may be desirable or undesirable with respect to management objectives.

Most studies focused on effects at population level, like protection of spawning stock biomass of exploited species (55 references), rehabilitation of demographic structure (35 references) and to a lesser extent exportation of biomass outside the MPA ( 24 references). At community level, the effects studied are mainly restoration of and changes in assemblage structure (22 references), protection of biodiversity (23 references), and indirect effects on algae and invertebrates (15 references). The other effects are less often addressed in the literature. In particular, habitat-related effects are rarely analysed in the articles reviewed (10 references). Note that the most frequently considered effects are all studied through visual observations of fish abundance and experimental fishing. Commercial catch and effort are seldom used in this kind of studies, except for evaluating the enhancement of fisheries yields around the MPA. To our knowledge, there is no empirical study for several effects mentioned in review articles, namely i) protecting intra-specific genetic diversity; ii) protecting and promoting biodiversity through protection of endangered species; iii) protecting against fishery-related depletion at community level; iv) facilitating recovery from 
Table 2. Expected MPA effects at population level, and variables measured to evidence these effects. Expected effects were listed from the references listed from review articles quoted at the beginning of Sect. 2.1. Variables measured were listed from the articles cited. LHT stands for Life History Traits.

\begin{tabular}{|c|c|c|}
\hline Expected effect & Variables measured & Studies \\
\hline $\begin{array}{l}\text { 1. Protecting criti- } \\
\text { cal spawning stock } \\
\text { biomass of species } \\
\text { from fishery-related } \\
\text { depletion }\end{array}$ & $\begin{array}{l}\text { density, biomass, Catch } \\
\text { Per Unit Effort (CPUE) } \\
\text { (also termed catch rate), } \\
\text { species richness of target } \\
\text { species group, frequency } \\
\text { of occurrence }\end{array}$ & $\begin{array}{l}\text { Bell (1983); Russ (1985); McClanahan and Muthiga (1988); Buxton and Smale } \\
\text { (1989); Russ and Alcala (1989); Cole et al. (1990); García-Rubies and Zabala (1990); } \\
\text { Yamasaki and Kuwahara (1990); Bennett and Attwood (1991); Roberts and Polunin } \\
\text { (1992); Armstrong et al. (1993); Buxton (1993); Holland et al. (1993); Polunin and } \\
\text { Roberts (1993); Francour (1994); McClanahan (1994); Harmelin et al. (1995); Dufour } \\
\text { et al. (1995); McClanahan and Kaunda-Arara (1996); Roberts (1995); Jennings et al. } \\
\text { (1995, 1996); Letourneur (1996); Russ and Alcala (1996a); Rakitin and Kramer } \\
\text { (1996); Stoner and Ray (1996); Watson et al. (1996); Edgar and Barrett (1997); } \\
\text { Sluka et al. (1997); Wantiez et al. (1997); Ciriaco et al. (1998); Russ and Alcala } \\
\text { (1998)a,b; Babcock et al. (1999); Chapman and Kramer (1999); Johnson et al. (1999); } \\
\text { La Mesa and Vacchi (1999); Millar and Willis (1999); Wallace (1999); Chiappone } \\
\text { and Sealey (2000); McClanahan et al. (1999); Chiappone et al. (2000); Francour } \\
\text { (2000); Kelly et al. (2000); McClanahan (2000); Paddack and Estes (2000); Tuya } \\
\text { et al. (2000); Jouvenel and Pollard (2001); McClanahan et al. (2001); Roberts et al. } \\
\text { (2001); Macpherson et al. (2002); Rowe (2002); Westera et al. (2003); Denny and } \\
\text { Babcock (2004); García-Charton et al. (2004) (55 references) }\end{array}$ \\
\hline $\begin{array}{l}\text { 2. Rehabilitating pop- } \\
\text { ulation age structure }\end{array}$ & $\begin{array}{l}\text { Average, modal, size } \\
\text { range, size distribution, } \\
\text { density or frequency of } \\
\text { large / old individuals }\end{array}$ & $\begin{array}{l}\text { Davis (1977); Buxton and Smale (1989); Yamasaki and Kuwahara (1990); Bennett } \\
\text { and Attwood (1991); Roberts and Polunin (1992); Armstrong et al. (1993); Buxton } \\
\text { (1993); Polunin and Roberts (1993); Francour (1994); Harmelin et al. (1995); } \\
\text { Dufour et al. (1995); Ferreira and Russ (1995); Letourneur (1996); McClanahan and } \\
\text { Kaunda-Arara (1996); Rakitin and Kramer (1996); Edgar and Barrett (1997); Sluka } \\
\text { et al. (1997); Wantiez et al. (1997); Piet and Rijnsdorp (1998); Babcock et al. (1999); } \\
\text { Chapman and Kramer (1999); Johnson et al. (1999); La Mesa and Vacchi (1999); } \\
\text { Wallace (1999); Chiappone and Sealey (2000); Chiappone et al. (2000); Kelly et al. } \\
\text { (2000); McClanahan (2000); Paddack and Estes (2000); Tuya et al. (2000); Jouvenel } \\
\text { and Pollard (2001); Béné and Tewfik (2003); Westera et al. (2003); Willis et al. } \\
\text { (2003a); Denny and Babcock (2004) (35 references) }\end{array}$ \\
\hline $\begin{array}{l}\text { 3. Exportation of } \\
\text { biomass }\end{array}$ & $\begin{array}{l}\text { Nb. recaptures, distance } \\
\text { travelled, trajectories, } \\
\text { density, mean size, } \\
\text { biomass and CPUE out- } \\
\text { side MPA, residence time }\end{array}$ & $\begin{array}{l}\text { Davis (1977); Gitschlag (1986); Buxton and Allen (1989); Davis and Dodrill (1989); } \\
\text { Yamasaki and Kuwahara (1990); Holland et al. (1993); Attwood and Bennett (1994); } \\
\text { McClanahan and Kaunda-Arara (1996); Rakitin and Kramer (1996); Russ and Alcala } \\
\text { (1996b); Zeller and Russ (1998); Chapman and Kramer (1999, 2000); Johnson et al. } \\
\text { (1999); Millar and Willis (1999); McClanahan and Mangi (2000); Eristhee and } \\
\text { Oxenford (2001); Meyer et al. (2000); Roberts et al. (2001); Willis et al. (2001, } \\
\text { 2003)a; Thorrold et al. (2001); Rowe (2002); Zeller et al. (2003) (24 references) }\end{array}$ \\
\hline $\begin{array}{l}\text { 4. Enhancing fish- } \\
\text { eries yield }\end{array}$ & $\begin{array}{l}\text { CPUE, fishing effort (nb. } \\
\text { gears, nb. fishers, spatial } \\
\text { distribution) }\end{array}$ & $\begin{array}{l}\text { Alcala (1988); Davis and Dodrill (1989); Alcala and Russ (1990); Yamasaki and } \\
\text { Kuwahara (1990); Bennett and Attwood (1991); McClanahan and Kaunda-Arara } \\
\text { (1996); Frank et al. (2000); Roberts et al. (2001); Rowe (2002) (9 references) }\end{array}$ \\
\hline $\begin{array}{l}\text { 5. Increasing fecun- } \\
\text { dity and production } \\
\text { of eggs and larvae }\end{array}$ & $\begin{array}{l}\text { Egg production, larvae } \\
\text { and nest density }\end{array}$ & $\begin{array}{l}\text { Stoner and Ray (1996); Ciriaco et al. (1998); Edgar and Barrett (1999); Chiappone } \\
\text { and Sealey (2000); Kelly et al. (2000); Valles et al. (2001); Rowe (2002); Béné and } \\
\text { Tewfik (2003) (8 references) }\end{array}$ \\
\hline $\begin{array}{l}\text { 6. Density-dependent } \\
\text { changes in LHT and } \\
\text { parasitism }\end{array}$ & $\begin{array}{l}\text { Sex ratio, parasite abun- } \\
\text { dance and prevalence, } \\
\text { condition index }\end{array}$ & Buxton (1993); Sasal et al. (1996); Edgar and Barrett (1999) (3 references) \\
\hline $\begin{array}{l}\text { 7. Protection of } \\
\text { recruitment }\end{array}$ & $\begin{array}{l}\text { Recruitment index, } \\
\text { Juvenile survival rate }\end{array}$ & Frank et al. (2000) \\
\hline
\end{tabular}

catastrophic human and natural disturbances; v) increasing population stability and resilience; vi) recolonisation of shallow habitats by target species; and vii) maintaining areas with undisturbed habitats.

Protection of genetic diversity (i) is probably limited by the relative recentness of most MPA and the scarcity of long term ecological studies in general. Protection of endangered species (ii) should be easier to evaluate, but restoration of long-lived species also requires medium to long term monitoring (see e.g. Bjorndal et al. 1999 for an example on marine turtles).

Protection of community against fishery-related depletion (iii) may be seen as a longer term perspective on the issue of sustainable management, addressing the question: "does the MPA guarantee that the community is going to recover from overexploitation?". Studying recovery from catastrophic events (iv) requires that recovery may be monitored over a 
Table 3. Expected MPA effects at the community level, and variables measured to evidence these effects. Expected effects were listed from the references listed from review articles quoted at the beginning of Sect. 2.1. Variables measured were listed from the articles cited. Species groups means families, trophic groups or vulnerable species.

\begin{tabular}{|c|c|c|}
\hline Expected effect & Variables measured & Studies \\
\hline $\begin{array}{l}\text { 8. Restoration of / } \\
\text { Changes in assemblage } \\
\text { structure }\end{array}$ & $\begin{array}{l}\text { Species composition } \\
\text { and relative abundance } \\
\text { of particular species } \\
\text { groups, species rich- } \\
\text { ness per group slope of } \\
\text { biomass spectrum, stom- } \\
\text { ach content composition }\end{array}$ & $\begin{array}{l}\text { Russ (1985); Russ and Alcala (1989); Polunin and Roberts (1993); McClanahan } \\
\text { (1994); Harmelin et al. (1995); Jennings et al. (1995); Letourneur (1996); } \\
\text { McClanahan and Kaunda-Arara (1996); Edgar and Barrett (1997, 1999); Wantiez } \\
\text { et al. (1997); Arias-Gonzales (1998); Piet and Rijnsdorp (1998); Russ and Alcala } \\
\text { (1998a,b); McClanahan et al. (1999); Paddack and Estes (2000); Macpherson et al. } \\
\text { (2002); Shears and Babcock (2002); Westera et al. (2003); Denny and Babcock } \\
\text { (2004); García-Charton et al. (2004) (22 references) }\end{array}$ \\
\hline $\begin{array}{l}\text { 9. Protection of } \\
\text { biodiversity }\end{array}$ & $\begin{array}{l}\text { Species richness and di- } \\
\text { versity indices, species- } \\
\text { area relationship }\end{array}$ & $\begin{array}{l}\text { Bell (1983); Russ (1985); Russ and Alcala (1989); Cole et al. (1990); García-Rubies } \\
\text { and Zabala (1990); Roberts and Polunin (1992); Dufour et al. (1995); Harmelin } \\
\text { et al. (1995); Jennings et al. (1995, 1996); Letourneur (1996); Rakitin and Kramer } \\
\text { (1996); Watson et al. (1996); Edgar and Barrett (1997); Wantiez et al. (1997); } \\
\text { Arias-Gonzales (1998); Russ and Alcala (1998b); Johnson et al. (1999); La Mesa } \\
\text { and Vacchi (1999); McClanahan et al. (1999); Francour (2000); Macpherson et al. } \\
\text { (2002); Denny and Babcock (2004) (23 references) }\end{array}$ \\
\hline $\begin{array}{l}\text { 10. Indirect effects on } \\
\text { algae and invertebrates } \\
\text { (cascade effect, } \\
\text { food-chain reactions) }\end{array}$ & $\begin{array}{l}\text { Invertebrate density, size } \\
\text { and weight, coral cover, } \\
\text { spatial distribution of } \\
\text { species, predation rate }\end{array}$ & $\begin{array}{l}\text { McClanahan and Muthiga (1988); Castilla and Bustamante (1989); Cole et al. } \\
\text { (1990); Engel and Kvitek (1998); Babcock et al. (1999); Edgar and Barrett (1997, } \\
\text { 1999); Epstein et al. (1999); McClanahan et al. (1999, 2001); Paddack and Estes } \\
\text { (2000); Tuya et al. (2000); Dulvy et al. (2002); Shears and Babcock (2002, 2003); } \\
\text { Westera et al. (2003) (15 references) }\end{array}$ \\
\hline $\begin{array}{l}\text { 11. Increasing } \\
\text { ecosystem stability and } \\
\text { resilience }\end{array}$ & $\begin{array}{l}\text { Temporal variability of } \\
\text { diversity, biomass and } \\
\text { density }\end{array}$ & Francour $(1994,2000)$ \\
\hline
\end{tabular}

Table 4. Expected MPA effects upon habitat, and variables measured to evidence these effects. Expected effects were listed from the references listed from review articles quoted at the beginning of Sect. 2.1. Variables measured were listed from the articles cited.

\begin{tabular}{|c|c|c|}
\hline Expected effect & Variables measured & Studies \\
\hline $\begin{array}{l}\text { Protecting essential habi- } \\
\text { tats for larvae settlement, } \\
\text { recruitment, spawning and } \\
\text { feeding } \\
\text { Maintaining areas with } \\
\text { undisturbed habitats }\end{array}$ & $\begin{array}{l}\text { density, biomass and } \\
\text { species richness of } \\
\text { epibenthos and en- } \\
\text { dobenthos, substrate } \\
\text { perturbations, CPUE } \\
\text { of exploited fish }\end{array}$ & $\begin{array}{l}\text { Castilla and Bustamante (1989); Edgar and Barrett (1999); Hoffman and Dolmer } \\
\text { (2000); Paddack and Estes (2000) (4 references) }\end{array}$ \\
\hline $\begin{array}{l}\text { Detrimental effects due to } \\
\text { non-exploitative uses }\end{array}$ & $\begin{array}{l}\text { density, biomass and } \\
\text { species richness of } \\
\text { epibenthos, substrate } \\
\text { perturbations }\end{array}$ & $\begin{array}{l}\text { Engel and Kvitek (1998); Epstein et al. (1999); Rouphael and Inglis (2001); Tratalos } \\
\text { and Austin (2001); Milazzo et al. (2002); Zakai and Chadwick-Furman (2002) } \\
\text { (6 references) }\end{array}$ \\
\hline
\end{tabular}

long period of time in both MPA and surrounding areas. Both iii) and iv) require long term studies. In addition, explicit quantitative models of exploited community dynamics may prove necessary to address point iii).

\subsection{Economic effects}

Contrary to studies of ecological effects and experiences in MPA implementation, the number of applications of economic analysis to assess MPA benefits is small (Talbot 1994; Hoagland et al. 1995; Farrow 1996). As underlined by Rudd et al. (2003), MPAs have rarely been the focus of rigorous policy analyses that consider a full range of economic costs and

\footnotetext{
3 e.g. trampling, erosion by divers, mooring iMPActs, food-chain reactions.
}

benefits, including management costs. A limited number of recent publications reviewed the economic effects of marine protected areas, either directly (Dixon 1993; Dixon et al. 1993; Crosby 1994; Hoagland et al. 1995; Pendleton 1995; Farrow 1996; Carter 2003) or via the discussion of the economic value of reef ecosystem goods and services (Hodgson and Dixon 1992; Spurgeon 1992; Lipton and Wellman 1995; Cesar 1996; Turner and Adger 1996; Moberg and Folke 1999; Ledoux 2002; Cesar et al. 2003).

Hoagland et al. (1995) is one of the rare references aiming at establishing a state of the art on assessing MPA net benefits. In their review, only a limited number of references primarily addressed the economic assessment of MPA in coral reef environments: 10 references (out of 61) dealt with the economic valuation of the costs and benefits associated to tropical MPAs, among which 3 references presented empirical estimates of 
Table 5. Expected economic effects of implementing a MPA, and variables measured to evidence these effects. References are presented according to type of contribution. In empirical studies, quantitative estimates obtained from data are provided. "Discussed in article" means that the subject is mentioned and discussed from a general and/or theoretical standpoint. Modelling studies present results from mathematical models to illustrate the subject.

\begin{tabular}{|c|c|c|c|}
\hline Expected priced effect & Variables measured & \multicolumn{2}{|c|}{ References } \\
\hline \multicolumn{4}{|c|}{ Financial effects of setting up and managing a MPA } \\
\hline \multirow[t]{2}{*}{$\begin{array}{l}\text { Costs of designing and } \\
\text { implementing a MPA }\end{array}$} & \multirow[t]{2}{*}{$\begin{array}{l}\text { Direct financial costs of setting up } \\
\text { a MPA } \\
\text { Costs of compensatory measures } \\
\text { for displaced activities }\end{array}$} & Empirical studies & $\begin{array}{l}\text { Dixon (1993); Dixon et al. (1993); Pendleton } \\
\text { (1995); Cesar (2002); Bhat (2003) }\end{array}$ \\
\hline & & Discussed in article & Meganck (1991); Turner and Adger (1996) \\
\hline \multirow[t]{2}{*}{$\begin{array}{l}\text { Management costs and } \\
\text { revenues }\end{array}$} & \multirow[t]{2}{*}{$\begin{array}{l}\text { Costs of management, monitoring } \\
\text { and enforcement } \\
\text { Revenues derived from charging } \\
\text { users of the MPA (as cost-recovery } \\
\text { and/or management instrument) }\end{array}$} & Empirical studies & $\begin{array}{l}\text { Dixon (1993); Dixon et al. (1993); Pendleton } \\
\text { (1995); Cesar (2002); Bhat (2003) }\end{array}$ \\
\hline & & Discussed in article & Turner and Adger (1996) \\
\hline \multicolumn{4}{|c|}{ Opportunity costs of protection } \\
\hline \multirow[t]{2}{*}{$\begin{array}{l}\text { Opportunity costs of } \\
\text { protection }\end{array}$} & \multirow[t]{2}{*}{$\begin{array}{l}\text { Value of foregone net benefits from } \\
\text { the various activity exclusions or } \\
\text { limitations resulting from the MPA }\end{array}$} & Empirical studies & Dixon (1993); Dixon et al. (1993) \\
\hline & & Discussed in article & Cesar (2002) \\
\hline \multicolumn{4}{|c|}{ Effects on commercial fisheries (other than opportunity costs of protection) } \\
\hline \multirow[t]{3}{*}{$\begin{array}{l}\text { Change in fishing ac- } \\
\text { tivity and net benefits } \\
\text { derived from fishing in- } \\
\text { side and outside the } \\
\text { MPA }\end{array}$} & \multirow[t]{3}{*}{$\begin{array}{l}\text { Changes in fishing effort, landings } \\
\text { in volume and value, catch per unit } \\
\text { of effort, operational costs of fish- } \\
\text { ing, income levels derived from } \\
\text { fishing, congestion costs (both } \\
\text { within and outside the MPA) }\end{array}$} & Empirical studies & Lipton and Wellman (1995); Cesar (2002) \\
\hline & & Discussed in article & Sumaila and Charles (2002) \\
\hline & & Modelling studies & $\begin{array}{l}\text { Holland and Brazee (1996); Hannesson (1998); } \\
\text { Conrad (1999); Holland (2000); Sanchirico } \\
\text { and Wilen (2001, 2002); Anderson (2002); } \\
\text { Boncoeur et al. (2002); Hannesson (2002); } \\
\text { Roberts and Sargant (2001); Rodwell et al. } \\
\text { (2001) }\end{array}$ \\
\hline \multicolumn{4}{|c|}{ Effects on recreation-based commercial activities (other than opportunity costs of protection) } \\
\hline \multirow[t]{2}{*}{$\begin{array}{l}\text { Change in recreation- } \\
\text { based activities, and as- } \\
\text { sociated net benefits to } \\
\text { private businesses }\end{array}$} & \multirow[t]{2}{*}{$\begin{array}{l}\text { Number of visits and gross expen- } \\
\text { diture directly related to the MPA, } \\
\text { net benefits to local recreation- } \\
\text { based businesses, net benefits } \\
\text { to international recreation-based } \\
\text { businesses }\end{array}$} & Empirical studies & $\begin{array}{l}\text { Dixon (1993); Dixon et al. (1993); Kenchington } \\
\text { (1993); Lipton and Wellman (1995); Pendleton } \\
\text { (1995); Turner and Adger (1996); Brown et al. } \\
\text { (2001); Cesar (2002); Bhat (2003) }\end{array}$ \\
\hline & & Discussed in article & Kenchington (1991); Badalamenti et al. (2000) \\
\hline $\begin{array}{l}\text { Public costs and } \\
\text { benefits associated } \\
\text { to the development } \\
\text { of recreation-based } \\
\text { commercial activities }\end{array}$ & $\begin{array}{l}\text { Changes in public revenue from } \\
\text { taxes and user fees on recreational } \\
\text { activities, and costs of public sup- } \\
\text { port to the recreation-based com- } \\
\text { mercial activities }\end{array}$ & Empirical studies & Dixon (1993); Dixon et al. (1993) \\
\hline
\end{tabular}

market values, and another 3 references reported empirical estimates of non-market values (Tables 5 and 6). Remaining references mostly comprised (i) economic valuation studies of tropical reef ecosystems, which can be useful to discuss the costs and benefits of ecosystem protection ( 8 references); (ii) theoretical approaches to coastal and marine protected areas valuation (17 references); and (iii) general problems of protected areas design and management, and tropical marine ecosystems management issues (15 references).

The present review of the more recent literature confirms this analysis. Although there is a growing interest for bio-economic modelling of area-based fisheries management measures (Holland 2000; Pezzey et al. 2000; Sanchirico and Wilen 2001; Sumaila and Charles 2002) few new empirical 
Table 6. Expected economic unpriced effects of implementing a MPA, and variables measured to evidence these effects. References are presented according to type of contribution. All references provide quantitative estimates for studying the effect mentioned, except those in italics that only discuss the subject.

\begin{tabular}{|c|c|c|}
\hline Expected unpriced effect & Variables measured & References \\
\hline \multicolumn{3}{|c|}{ Benefits to recreational users (extractive and non-extractive use values) } \\
\hline $\begin{array}{l}\text { Benefits associated to changes in the } \\
\text { number and value of recreational } \\
\text { experience }\end{array}$ & $\begin{array}{l}\text { Variation in number of visits directly related } \\
\text { to the MPA, variation in consumer surplus as- } \\
\text { sociated to a visit }\end{array}$ & $\begin{array}{l}\text { Leeworthy (1991); Dixon et al. (1993); Lipton and } \\
\text { Wellman (1995); Pendleton (1995); Brown et al. } \\
\text { (2001); Arin and Kramer (2002) }\end{array}$ \\
\hline \multicolumn{3}{|c|}{ Benefits of the protection of ecosystem services (indirect-use and non-use values) } \\
\hline $\begin{array}{l}\text { Benefits associated to changes in } \\
\text { the status of the protected reef } \\
\text { ecosystem }\end{array}$ & $\begin{array}{l}\text { Variation in indirect-use and non-use value of } \\
\text { ecosystem services }\end{array}$ & $\begin{array}{l}\text { Farrow (1996); Spash et al. (1998); Bhat (2003); } \\
\text { Gustavson (2002) }\end{array}$ \\
\hline \multicolumn{3}{|l|}{ Longer term costs of MPA overuse } \\
\hline $\begin{array}{l}\text { External costs of the development } \\
\text { of recreational activities (ecological } \\
\text { impacts and loss of amenity) }\end{array}$ & $\begin{array}{l}\text { Variation in number of visits directly related } \\
\text { to the MPA, congestion costs, consumer sur- } \\
\text { plus associated to the visit of a degraded } \\
\text { ecosystem }\end{array}$ & $\begin{array}{l}\text { Geen and Lal (1991); Kenchington (1991); Dixon } \\
\text { (1993); Dixon et al. (1993); Davis and Tisdell } \\
(1995,1996) ; \text { Brown et al. (2001) }\end{array}$ \\
\hline
\end{tabular}

analyses have been published. Only some of the goods and services provided by reef ecosystems have been included in published valuation exercises, mostly focusing on tourism and recreation, and to a lesser extent on fisheries (Moberg and Folke 1999).

Two kinds of economic effects were distinguished: priced effects (Table 5) that refer to the effects on human activity that can be measured using market prices, and unpriced effects (Table 6) that refer to the effects that require the application of specific valuation methods as they relate to goods and services not traded in markets (see e.g. Turner and Adger 1996). Priced effects described in the literature include financial effects of setting up and managing MPAs, the opportunity costs of protection (i.e. foregone benefits for the users affected by MPA implementation), and the costs and benefits to ecosystem users, in particular commercial fisheries and recreational businesses (Table 5). While MPAs are often assumed to be a preferred option in terms of ease of management, there are few published estimates of the costs of setting up MPAs and/or costs of monitoring and enforcement of effectively applied MPAs (Hoagland et al. 1995). The financial effects of setting up and managing a MPA include design and implementation costs ( 7 references), management costs and revenues (6 references). In addition to these financial effects, protection usually involves restrictions of access such as limitations or prohibitions on fishing, collecting, mineral exploitation, diving, boating, etc. (Crosby 1994). These were considered in several references as potential significant sources of opportunity costs for MPAs (3 references, Table 5).

Expected economic effects of MPAs on commercial fisheries include changes in fishing activity and in net benefits derived from fishing both inside and outside the MPA. Inside the MPA, they include the costs of new constraints on harvesting and benefits of decreased fishing pressure for the remaining fishing activities. Outside the MPA, they include the costs of displaced effort for fishers and the benefits due to spillover effects. While there has been a growing number of studies discussing these expected impacts from a theoretical perspective (11 references), few empirical applications have been published, particularly in coral reef ecosystems (2 references, Table 5).

More empirical work was carried out on the effects of MPA on recreation-based uses of coral reef ecosystems ${ }^{4}$, i.e. associated net benefits to private businesses (13 references), and public costs and benefits associated to these changes ( 2 references). An important issue here is the allocation of benefits and costs within the local economy, and between the local economy and the rest of the world (Crosby 1994).

Regarding unpriced effects (Table 6), references discuss (and sometimes estimate) the value of changes in the status of protected ecosystems to non-commercial users (7 references), indirect users of ecosystem services and non-users (4 references). Non-commercial users are those who derive value from both extractive and non-extractive uses of the ecosystem, but references mainly consider changes affecting recreational users such as divers. Indirect users benefit from the protection of the ecosystem through the preservation of the services it provides, e.g. the protection from erosion and storm surge afforded by reefs to coastal areas, or the role of seagrass beds in the ecological dynamics of reef species having direct use value (see Holmlund and Hammer 1999 for a discussion of ecosystem services generated by fish populations). Non-users are people granting value to the preservation of coral reef ecosystems independently of any present or future use.

Finally, the existing literature also discusses non-market consequences of the development of recreational activities within MPA, which can lead to overuse if no controls on access are put in place, with negative impacts on the ecosystem and the value of the services it provides ( 8 references).

\subsection{Social effects}

While we have focused in the previous point on the economic valuation of MPAs, their other social consequences should also be acknowledged as important components of

\footnotetext{
${ }^{4}$ With the limitation of some studies to an assessment of the gross expenditure directly associated to the protected areas (see below).
} 
MPA assessment. In particular, the perception of people directly and indirectly affected by the MPA has been stressed as crucial, as it may affect the degree of support or opposition to MPAs, with consequences on the effectiveness of protection (Fiske 1992; Alder 1996; Wolfenden et al. 1998; Sant 1996; Cocklin et al. 1998; Schafer and Benzaken 1998; Suman et al. 1999). In practice, perception is measured via surveys directed at eliciting people's attitudes towards existing (Alder 1996; Shafer and Benzaken 1997; Suman et al. 1999) or projected (Sant 1996) MPAs. Beyond the few references dealing with the perception and attitudes of stakeholders regarding MPAs (Wolfenden et al. 1994; Sant 1996; Cocklin et al. 1998; Schafer and Benzaken 1998; Suman et al. 1999), published assessments of MPA social effects mainly relate to user involvement in co-management strategies (Elliott et al. 2001; Clifton 2003; Scholz et al. 2004), and to the assessment of the general socioeconomic factors influencing MPA success (Pollnac et al. 2001).

Social effects of MPAs are poorly documented compared to ecological and economic effects. There are two main reasons to this. First, social effects per se are not easily distinguished from other effects. For instance, local employment in tourism, benefits and costs of the informal sector, costs of local access to the park were listed by Brown et al. (2001) as social criteria for assessing management options in the case of a reef marine park in Tobago. However, such criteria might as well be considered as economic. Secondly, social effects are rather viewed as constraints to the achievement of MPA management objectives, than as real expectations.

In the present article, social effects of MPAs (Table 7) were classified according to three general objectives found in the literature: i) reducing and anticipating conflicts between different user groups; ii) improving visitors' satisfaction; and iii) increasing knowledge about marine ecosystems and biodiversity (for both tourists and local dwellers) $)^{5}$. Objective i) is an issue even when ecological and economic objectives are reached, because conflicts may arise if benefits are not shared. Participation and sharing of benefits are then an associated objective of i) (Christie et al. 2004). Effects linked with objective iii) are the most frequently studied (6 references). Target groups are the public or the research community (Davis and Tisdell 1995; Boersma and Parrish 1999). MPAs are seen as tools that facilitate monitoring for the assessment of anthropic consequences on coral ecosystems. Yanez Arancibia et al. (1999) consider MPAs as a suitable place for integrating science and management to the benefit of both. MPAs are also seen as a good laboratory to study Integrated Coastal Zone Management (ICZM) (David 1998).

The improvement of tourists' and local dwellers' satisfaction (objective ii) (5 references) relates to the increase in recreational facilities (Davis and Tisdell 1995), the conservation of beautiful and attractive landscapes (Boersma and Parrish 1999), the improvement of the status of marine life and

\footnotetext{
5 Note that the latter two categories of effects can in principle be included in a total economic value analysis of MPA effects. Indeed, the satisfaction of MPA users has been taken into account in a number of valuation studies. But the effects have also been measured using other approaches such as direct interviews of MPA users, which are accounted for in Table 7 .
}

habitats (Davis and Tisdell 1995), and the protection of archaeological, historical and cultural sites (Davis and Tisdell 1995; Boersma and Parrish 1999). Reducing conflicts between different user groups (objective i)) via the zoning design and management plan is a key objective of MPAs (Suman et al 1999; Day 2002), but studies of related effects are scarce (Table 7). Note that the effects related to objective i) are mostly negative, but that some effects classified under effect ii) may also be seen as positive effects that may contribute to reduce conflicts between user groups.

Among positive effects, community participation in decision making is pointed out as a key for the success of MPA implementation ( 5 references). This is illustrated by Pollnac et al. (2001) in the case of community-based MPAs in the Philippines. However, community participation is not a sufficient condition as underlined by Christie et al. (2002), and other management measures are needed at a larger scale.

\section{Potential indicators for the assessment of MPA impacts}

In the previous section, we listed the variables studied in the surveyed literature for assessing a variety of MPA-related effects. To complete the definition of potential quantitative indicators for measuring the impact of MPA, we further need to specify the scale at which the variable was measured. In the literature, a given variable may have been used at several scales, e.g. density per species, density of species group or total density of fish community (Tables 2 and 3 ). A variable measured at a given level is termed a metric in the rest of the article. A metric constitutes a potential indicator for one or several effects related to the existence of a MPA.

In this section, we considered the metrics used in the surveyed literature, and we assessed their performance as potential indicators of the MPA-related effects identified in Sect. 3. In the case of ecological indicators, we proposed an assessment based on the literature review. In the case of economic and social indicators, the number of references being much lower, we critically discussed the indicators identified in Sects. 3.2 and 3.3. It is not the purpose of this paper to carry out a thorough quantitative analysis of the potential indicators identified from the literature, but rather to highlight their strong and weak points regarding the objective of assessing MPA impact.

\subsection{Performance of ecological indicators}

The performance criteria used are relevance and effectiveness (see Ferraris et al. 2005) for extensive definitions of indicator properties). The relevance of an indicator illustrates the link between the indicator and the effect it is supposed to indicate. The effectiveness of an indicator gathers the concept of statistical power, precision, variability, sensitiveness and the fact that there are reference values or thresholds against which the indicator can be tested. Such measures pertain to quantitative indicators which are the scope of this paper. 
Table 7. Social effects of implementing MPAs, key factors of success, and variables measured to evidence of these effects. All references provide quantitative estimates for studying the effect mentioned, except those in italics that only discuss the subject.

\begin{tabular}{|c|c|c|c|}
\hline Objectives & Variables measured & Effect & References \\
\hline \multirow{7}{*}{$\begin{array}{l}\text { Reducing } \\
\text { conflicts } \\
\text { between } \\
\text { user groups }\end{array}$} & $\begin{array}{l}\text { Complains collected via } \\
\text { questionnaires or focus groups }\end{array}$ & $\begin{array}{l}\text { Strong frustration of local fishers concerning } \\
\text { decrease in fishing effort }\end{array}$ & $\begin{array}{l}\text { Suman et al. (1999) } \\
\text { Scholz et al. (2004) }\end{array}$ \\
\hline & $\begin{array}{l}\text { Complains collected via } \\
\text { questionnaires or focus groups or } \\
\text { interviews }\end{array}$ & $\begin{array}{l}\text { Frustration of local stakeholders concerning MPA } \\
\text { boundaries and zoning, and the current management } \\
\text { system }\end{array}$ & $\begin{array}{l}\text { Sant (1996) } \\
\text { Clifton (2003) }\end{array}$ \\
\hline & $\begin{array}{l}\text { Complains collected via } \\
\text { questionnaires or focus groups }\end{array}$ & $\begin{array}{l}\text { Frustration of local fishers concerning the restriction } \\
\text { of activities }\end{array}$ & Sant (1996) \\
\hline & $\begin{array}{l}\text { Perception collected via } \\
\text { questionnaires or interviews }\end{array}$ & $\begin{array}{l}\text { Distrust of scientists and MPA managers with respect } \\
\text { to stakeholders (mainly fishers), } \\
\text { concerning the replenishment concept and the } \\
\text { integration of their point of view in decision- making }\end{array}$ & $\begin{array}{l}\text { Suman et al. (1999) } \\
\text { Scholz et al. (2004) }\end{array}$ \\
\hline & $\begin{array}{l}\text { Number of offences noted by the } \\
\text { rangers }\end{array}$ & Poaching & Clifton (2003) \\
\hline & $\begin{array}{l}\text { Frequency of meetings and focus } \\
\text { groups between the public and the } \\
\text { managers }\end{array}$ & $\begin{array}{l}\text { Community participation in MPA planning and } \\
\text { decision making }\end{array}$ & $\begin{array}{l}\text { Wolfenden et al. (1994); } \\
\text { Coklin et al. (1998); } \\
\text { Suman et al. (1999); } \\
\text { Pollnac et al. (2001); } \\
\text { Clifton (2003) }\end{array}$ \\
\hline & $\begin{array}{l}\text { Distance of the MPAside villages } \\
\text { from local authorities }\end{array}$ & Inputs from local authorities & Pollnac et al. (2001) \\
\hline \multirow{6}{*}{$\begin{array}{l}\text { Improve } \\
\text { satisfaction } \\
\text { of visitors and } \\
\text { local dwellers }\end{array}$} & $\begin{array}{l}\text { Capacity to organise workshops, } \\
\text { number of expert visits }\end{array}$ & $\begin{array}{l}\text { Continuing advice from organizations supervising } \\
\text { and funding MPA projects }\end{array}$ & Pollnac et al. (2001) \\
\hline & $\begin{array}{l}\text { Life expectation of projects and } \\
\text { amount of income generated }\end{array}$ & Successful alternative income projects & Pollnac et al. (2001) \\
\hline & $\begin{array}{l}\text { Perception collected via } \\
\text { questionnaires or focus groups } \\
\text { Willingness of diver tourists to pay } \\
\text { to visit marine sanctuaries }\end{array}$ & $\begin{array}{l}\text { Satisfaction of local stakeholders, mainly } \\
\text { conservationist group members or tourists } \\
\text { concerning the improvement of marine life status }\end{array}$ & $\begin{array}{l}\text { Sant (1996); Suman et al. } \\
\text { (1999); Arin and Kramer } \\
\text { (2002) }\end{array}$ \\
\hline & $\begin{array}{l}\text { Perception collected via } \\
\text { questionnaires or focus groups }\end{array}$ & $\begin{array}{l}\text { Satisfaction of local stakeholders concerning tourism } \\
\text { and job opportunities and the increase in recreational } \\
\text { activities }\end{array}$ & $\begin{array}{l}\text { Sant (1996); Suman et al. } \\
\text { (1999) }\end{array}$ \\
\hline & Size of the population & Homogeneity of MPAside dwelling populations & Pollnac et al. (2001) \\
\hline & $\begin{array}{l}\text { Perceived crisis in terms of } \\
\text { reduced fish population before the } \\
\text { MPA project started }\end{array}$ & $\begin{array}{l}\text { Awareness of MPAside dwelling populations about } \\
\text { ecosystem conservation }\end{array}$ & Pollnac et al. (2001) \\
\hline $\begin{array}{l}\text { Increasing } \\
\text { knowledge } \\
\text { about marine } \\
\text { ecosystems and } \\
\text { biodiversity }\end{array}$ & $\begin{array}{l}\text { Creation of a community-based } \\
\text { management system } \\
\text { Participative community } \\
\text { co-management }\end{array}$ & $\begin{array}{l}\text { Incorporation of local ecological knowledge in policy } \\
\text { processes including MPA design and management } \\
\text { plan }\end{array}$ & $\begin{array}{l}\text { Scholz et al. (2004) } \\
\text { Russ and Alcala (1999); } \\
\text { Day (2002) }\end{array}$ \\
\hline
\end{tabular}

\subsubsection{Relevance}

The relevance of a potential indicator was assessed through the number of times it was used for assessing an effect in the reviewed literature. We thus assumed that the more often a metric was used for assessing a given effect, the stronger the link between the metric and the effect. To account for size effects linked to the scale of the metrics (e.g. population level versus community level), we reported in addition the number of articles in which metrics were used. It should be noted that this measure of relevance is subject to publication bias, i.e. the review can only report the content of the article. To reduce this bias, metrics were counted in the reviewed papers from both
Method section and Results section, because the latter may not mention all metrics studied.

The proposed estimation of relevance leads us to distinguish metrics widely used in articles (here metrics used in more than five articles) (Table 8) from metrics rarely used (Table 9). A few metrics were very often used but mostly for a single effect: total density and species density to assess the effects on target populations, mean size of species for evaluating the rehabilitation of population age structure, movement patterns for studying the potential for biomass exportation; total species richness for assessing the success of management measures to protect biodiversity, and species richness per family for studying the degree in which assemblage structure 
Table 8. Relevance of metrics for each ecological effect, as estimated by the total number of times (over articles) the metrics was used, and between parentheses the number of articles in which a given metrics was used. Only metrics used in more than five articles were reported. Biomass and density are respectively in weight per surface area and in numbers of individuals per surface area. Profiles refer to multivariate relative measures per species or species group (e.g. families). CPUE is either commercial or scientific. Common species are also termed important species, frequently observed species. Total refers to all species, although pelagic species and/or cryptic species are sometimes excluded. According to references, fishable species are termed fished species, commercial species, vulnerable species, target species, exploitable species or exploited species. Size range includes maximum size. Species stage includes age group, size group, maturity group. Total species richness either refers to total fish, or total invertebrates, or total algae depending on effect.

\begin{tabular}{|c|c|c|c|c|c|c|c|c|c|c|c|c|}
\hline Variable & Metrics & 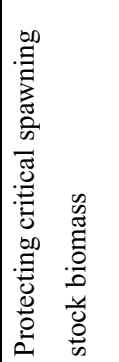 & 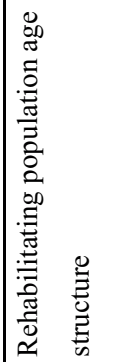 & 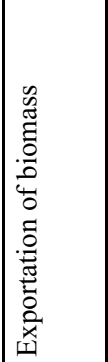 & 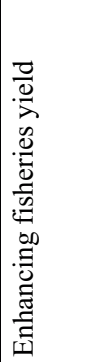 & 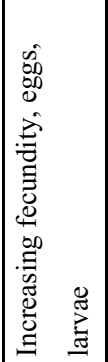 & 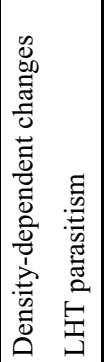 & 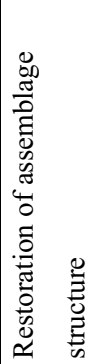 & 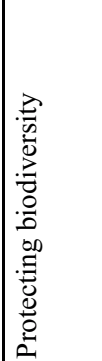 & 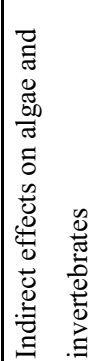 & 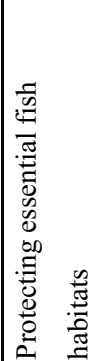 & 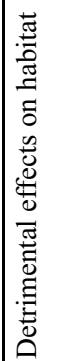 \\
\hline biomass & total & $27(6)$ & & $1(1)$ & $1(1)$ & & & & $8(1)$ & & & \\
\hline biomass & family & $36(7)$ & & & & & 9 & (1) & & & & \\
\hline biomass & trophic group & $26(4)$ & & & & & & & & & & \\
\hline biomass & species or genus & $178(6)$ & $124(5)$ & & & & & & & $1(1)$ & & \\
\hline density & total & $42(16)$ & & & & & & 8 & (1) & & & \\
\hline density & total over fishable species & $11(5)$ & & & & & & & & & & \\
\hline density & family & $129(13)$ & & & & & & $18(2)$ & $5(1)$ & $2(1)$ & & \\
\hline density & trophic group & $20(6)$ & & & & & & & & & & \\
\hline density & size group & $4(3)$ & $1(1)$ & & & & & $3(1)$ & & $4(1)$ & & \\
\hline density & species or genus & $712(29)$ & & $12(2)$ & & & & & & $57(9)$ & & \\
\hline density & species stage & $21(5)$ & $17(4)$ & & & $4(2)$ & & & & & & \\
\hline relative density & species stage & $8(4)$ & $9(4)$ & & & $2(1)$ & $4(1)$ & & & & & \\
\hline density profile & species & $1(1)$ & & & & & & $8(6)$ & & $3(1)$ & & \\
\hline species richness & total & & & $2(1)$ & & & & $3(1)$ & $22(14)$ & $3(1)$ & & \\
\hline species richness & family & $58(1)$ & & & & & & $136(7)$ & $2(1)$ & & & \\
\hline mean size & species or genus & $3(1)$ & $236(19)$ & & $10(1)$ & & $2(1)$ & & & $23(4)$ & & \\
\hline size distribution & species & $14(1)$ & $30(6)$ & & & & $4(1)$ & & & & & \\
\hline movement patterns & species & & & $31(10)$ & & & & & & & & \\
\hline home range & species & & & $15(8)$ & & & & & & & & \\
\hline site fidelity & species & $2(1)$ & & $9(6)$ & & & & & & & & \\
\hline CPUE & total or per gear & $7(3)$ & & $8(3)$ & $10(3)$ & & & & & & $1(1)$ & \\
\hline CPUE & species & $57(6)$ & $2(1)$ & & $10(1)$ & & & & & & & \\
\hline benthic cover & macrobenthos type & & & & & & & & & $29(5)$ & $5(4)$ & $8(1)$ \\
\hline
\end{tabular}

returned to unexploited levels. Metrics were often used to study more than one effect, in particular biomass- and densitybased metrics (Table 8).

Results confirmed that, in addition to effects not studied in the literature (see Sect. 3.1), several effects have rarely been evaluated, namely protecting recruitment; increasing fecundity, egg and larvae production; the occurrence of density-dependent effects; improving ecosystem stability; and protecting essential fish habitats (Table 8).

It is also interesting to take a look at metrics rarely used, which relevance is low given our definition (Table 9). There is a variety of such metrics, and some of them will probably prove useful in future studies, either because of their statistical properties (e.g. robustness), or their complementarity to others. 
Table 9. Metrics used in less than five articles, for each ecological effect.

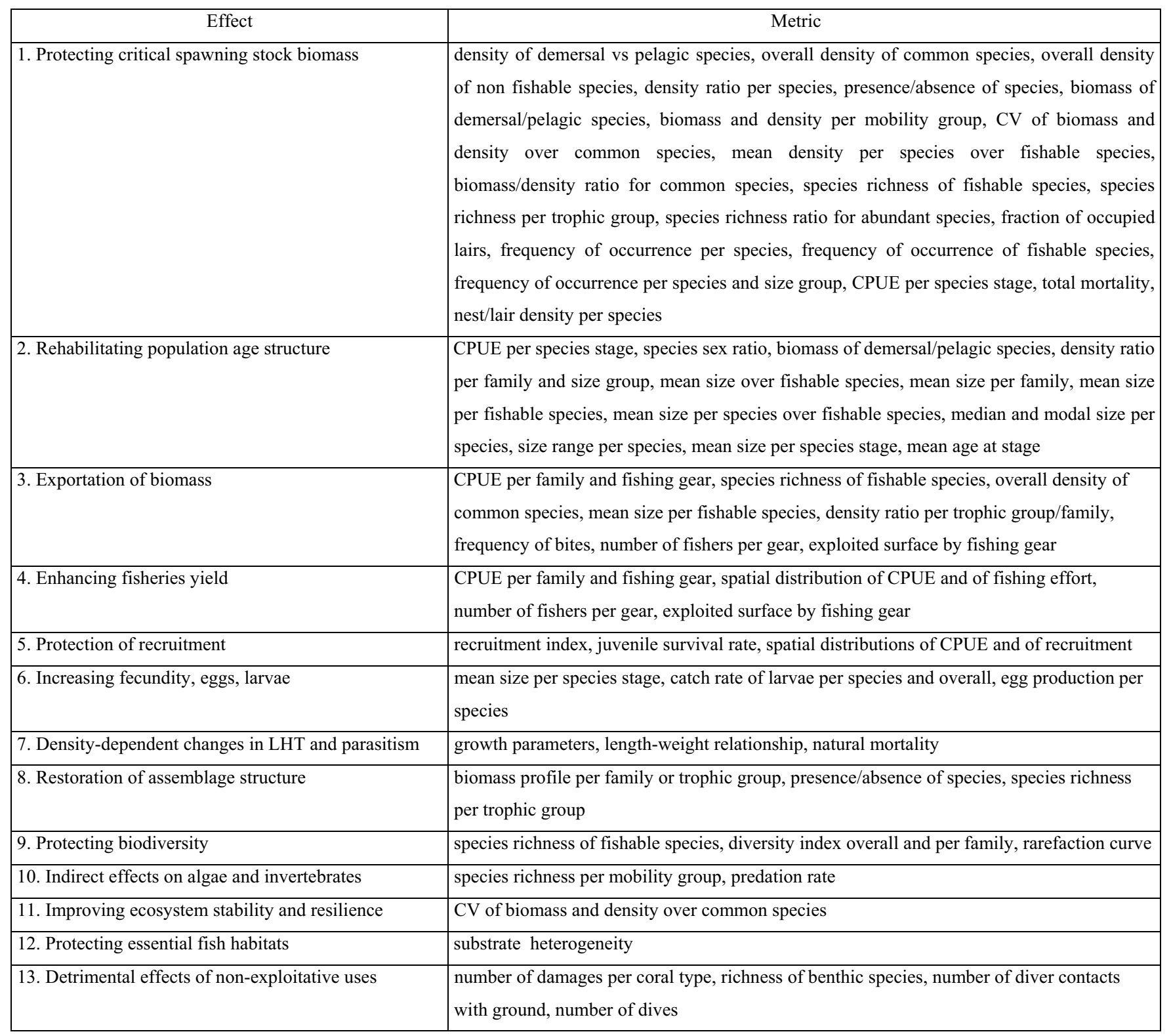

But we could not study their effectiveness from the existing literature (see below).

\subsubsection{Effectiveness}

The effectiveness of a potential indicator was assessed from the proportion of significant effects found in the reviewed studies, whether these effects were positive or negative. The significance of a result is mostly tied to the power of the analysis, which in turn depends on the variability of the system, the sensitivity of the metric to the effect tested, and the experimental design studied (Ferraris et al. 2005). Therefore, effectiveness may thus be seen as a proxy to the statistical power of the analysis. In this definition, we did not account for the existence of reference values or thresholds. All reviewed studies were based on empirical assessments and therefore did not provide reference values. Note however that in such studies, the provision of control sites somehow addresses the issue of reference values. In practice, the effectiveness of a potential indicator was calculated for each effect as the ratio of the number of times it gave a significant result divided by the number of times it was used, across all studies based on inferential statistical analysis. Metrics based on descriptive methods, i.e. non-inferential methods, were considered in the relevance, but excluded from the calculation of effectiveness; therefore numbers may not correspond between Tables 8 and 10. Being based on a ratio, effectiveness was only calculated for effects that were assessed in a sufficient number of studies (metrics from Table 8).

Like relevance, this measure of effectiveness is subject to publication bias, non-significant results being generally less well reported than significant ones. Again, we relied on 
Table 10. Effectiveness of metrics used in the literature. Descriptive uses of metrics were excluded from computations. Eff. means effectiveness. $n$ is the number of articles from which the effectiveness was calculated (each article generally includes several uses of the metric).

\begin{tabular}{|c|c|c|c|c|c|c|c|c|c|c|c|c|c|}
\hline & Metric & $\begin{array}{l}0 \\
0 \\
0 \\
0 \\
0 \\
0 \\
0 \\
0 \\
0\end{array}$ & 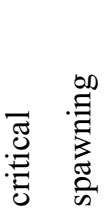 & 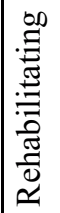 & 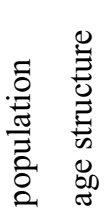 & 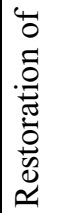 & 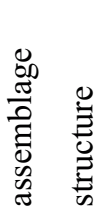 & 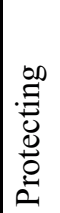 & 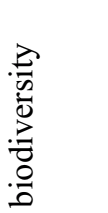 & 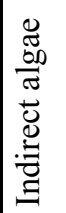 & 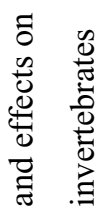 & 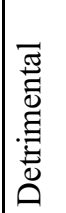 & 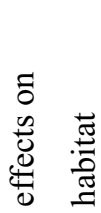 \\
\hline Variable & Scale & $n$ & Eff. 1 & $n$ & Eff. 2 & $n$ & Eff. 3 & $n$ & Eff. 4 & $n$ & Eff. 5 & $n$ & Eff. 6 \\
\hline biomass & total & 6 & 85 & & & & & 1 & 88 & & & & \\
\hline biomass & family & 7 & 72 & & & & & & & & & & \\
\hline biomass & trophic group & 4 & 85 & & & & & & & & & & \\
\hline biomass & species or genus & 6 & 39 & 5 & 35 & & & & & 1 & 100 & & \\
\hline density & total & 15 & 56 & & & & & 1 & 38 & & & & \\
\hline density & total fishable species & 5 & 82 & & & & & & & & & & \\
\hline density & family & 12 & 50 & & & & & 1 & 60 & 1 & 100 & & \\
\hline density & trophic group & 6 & 95 & & & & & & & & & & \\
\hline density & size group & 3 & 75 & 1 & 100 & 1 & 0 & 2 & 50 & & & & \\
\hline density & species or genus & 29 & 41 & & & & & & & 9 & 39 & & \\
\hline density & species stage & 5 & 67 & 4 & 71 & & & & & & & & \\
\hline relative density & species stage & 2 & 83 & 2 & 71 & & & & & & & & \\
\hline density profile & species & 1 & 100 & & & 2 & 67 & & & & & & \\
\hline species richness & total & 3 & 33 & & & 1 & 0 & 13 & 59 & 1 & 50 & & \\
\hline species richness & family & 1 & 34 & & & 6 & 41 & 2 & 0 & & & & \\
\hline mean size & species or genus & 1 & 33 & 18 & 38 & & & & & 4 & 39 & & \\
\hline size distribution & species & 5 & 95 & 5 & 56 & & & & & & & & \\
\hline CPUE & total & 3 & 60 & & & & & & & & & & \\
\hline CPUE & species & 5 & 40 & & & & & & & & & & \\
\hline benthic cover & macrobenthos type & & & & & & & & & 4 & 68 & 1 & 100 \\
\hline
\end{tabular}

the Method section. Another drawback of this approach pertains to the lack of coherence in experimental designs across studies. However, few articles contained sufficiently explicit information to account for this. Still, we believe it is useful to carry out this kind of meta-analysis, and we think this measure of effectiveness is suitable for qualitative comparisons across metrics.

The first observation is that few metrics have been widely used, since only 17 out of 41 combinations between metrics and effects were used in more than five reviewed studies (Table 10). For the first effect, the effectiveness of the most often used metrics ranges from ca. $40 \%$ (biomass and density per species) to $85 \%$ (total biomass). Total density performed relatively poorly $(56 \%)$, but, interestingly, total density computed over fishable species worked better $(82 \%)$.
Mean size showed surprisingly poor effectiveness (38\%) as an indicator to assess the ability of MPAs to rehabilitate population age structure. Population size distribution was more effective for this effect (56\%), this metric being also reasonably well related (95\%) to the potential of MPAs to increase population abundance.

The expected restoration of assemblage structure was better assessed by density profiles (67\% of effectiveness) than through the species richness of key families (41\%), although the latter was more often used than the former. Density profiles were generally analysed through multivariate methods. Total species richness appeared as a relatively effective indicator (59\% effectiveness).

The study of indirect effects of protection on algal and invertebrate assemblages (sometimes referred as "cascade 
effects" of protection) was mostly approached through algae or invertebrate species (or genus) density or cover, but its effectiveness was relatively low (39\%); other metrics could prove more effective, but their low utilization rate prevented us from assessing their performance.

If one excludes metrics rarely used for one effect, most efficient metrics were density per trophic group for effect 1 and size distribution for effect 2 (95\% effectiveness for each).

\subsection{Which indicators for the economic effects of MPA?}

The small number of empirical studies of the economic impacts of MPAs made it difficult to carry out the same type of assessment as in Subsection 4.1. Rather, several methodological points should be raised with respect to indicator selection.

In principle, the economic effects of an MPA should be defined as the difference in total net economic benefits derived from the ecosystem with and without MPA (Pendleton 1995). Such differences should be calculated from the measurement of variations in the benefits and costs associated to changes in ecosystem quality and uses that result from reef protection. The metrics used in empirical studies of Tables 5 and 6 may not reflect the true economic effects of MPAs for three reasons.

First, the metrics used often referred to economic impacts of MPAs, and not to their economic value. We illustrate the difference between these two concepts by the example of accidental pollutions. Resulting cleanup activities may be regarded as having a positive economic impact, but they also have a negative economic value, since cleaning uses resources that would have been otherwise diverted to a more valuable purpose had the pollution not occurred. The key difference between the economic impacts and the economic value of an activity lies in the opportunity costs of the resources used in this activity. Hence, economic impacts relate to the effects of an MPA on levels of economic activity, measured e.g. in the case of recreational activities, through gross expenditure by visitors and ensuing revenues to the local and international tourism industry and to the public budget via taxes. In contrast, measuring the economic value of an MPA requires the calculation of variations in total consumer and producer surplus associated to MPA existence. Total producer surplus is calculated as a sum of net benefits to producers, taking into account both production and opportunity costs. Total consumer surplus is derived from the demand function for the goods and services considered, e.g. visits to the area in the case of recreation (see Pendleton 1995 for an application to the Bonaire Marine Park).

The use of indicators of the economic impacts of MPAs, rather than indicators of their economic value, is primarily due to the difficulties in estimating producer surplus and demand functions for the goods and services provided by MPAs. In comparison, the information required to assess economic impacts (e.g. number of visitors and average expenditure per visitor in the case of recreational uses) is more accessible. For the same reason, most studies indeed focus on partial rather than total value analysis, e.g. by dealing only with the measurement of a particular economic effect (Tables 5 and 6).

Second, valuation studies often focused on the value of ecosystem goods and services, rather than on changes in their value due to the protection provided by marine parks. For example, they assessed the overall recreational benefits associated to a particular reef area, rather than the variation in these benefits entailed by the implementation of an MPA. Assessing the economic effects of a MPA thus requires the comparison of a scenario with and a scenario without the MPA, taking into account the changes in ecosystem quality and uses resulting from its creation or disappearance. Aside from the recent bio-economic modelling work focusing on the implications for fisheries of creating a closed area (Table 5), there has been little theoretical or empirical work to date along this line.

Third, because the changes that need to be measured are bound to occur over a period of time, economic assessment of MPAs should look at discounted net benefits over such a period (Pendleton 1995). Future costs and benefits occurring only in a distant future may weigh little from a present value perspective.

\subsection{Social effects of MPAs: Perceptions, attitudes and conflicts}

Given the scope of the paper, the paucity of empirical studies in the literature precluded any attempt to propose (not even evaluate) indicators for social effects of MPAs. The literature that can lead to indicator definition revolves around the issues of perception, attitudes and relationships between and among stakeholders, users and managers. Interviews and questionnaires are the appropriate way of collecting information in this purpose. Metrics to be used should logically be similar to those used in other fields of social sciences, but in the case of MPA, this kind of study is very little developed to date.

According to the literature, the conflicts between the stakeholders living around MPAs, and between these stakeholders and the MPA managers were the only factor which can be classified both as expected social effect and effective social effect of MPAs' implementation. According to our expertise, they are both cause and consequence of MPA failures. Due to its holistic nature, the number of conflicts per year is a potentially interesting indicator to assess the social sustainability of any MPA. It could be measured via interviews of local stakeholders. Pollnac et al. (2001) stress that the involvement of local stakeholders in MPA implementation and compliance to MPA management rules are two key factors of success, and that violation rates are not a good indicator of compliance to the rules, as they may be high where enforcement is strong, and low where it is poor. Therefore, these authors decided to have an expert panel rank the local stakeholders from 0 to 5. Similar approaches could be used to assess the degree of involvement of local stakeholders in MPA implementation.

Unlike ecological and economic studies, social studies about MPA effects are mostly in the grey literature, technical documents, reports or in books and proceedings. In France for instance, social scientists mainly publish in books in French or national symposia proceedings. This literature could not be integrated in the paper, and therefore the perception of social research on MPA may be biased if solely based on primary literature. 
In addition, most studies dealing with social considerations of MPA are mainly descriptive, and it is difficult to derive potential indicators, even qualitative ones, from such approaches.

Nevertheless, we believe that social indicators are needed for a better assessment of the social consequences of MPA, and particularly to identify crisis stages through threshold values.

A holistic indicator of MPA success may also be the simple fact that the MPA continues to be effectively managed and funded several years after its establishment.

\section{Conclusion}

As in many studies of anthropic pressure on marine ecosystems, economic aspects and even more so social aspects are apparently less documented than ecological effects, even though this conclusion might have been mitigated, had grey literature been taken into account. In the light of these differences, distinct approaches were undertaken for each discipline.

Existing literature precludes the identification of indicators for social effects. Economic indicators were also difficult to isolate as the literature does not really address the economic effects of MPAs, but either focus on a partial analysis of MPA effects, or refer to effects on economic activities, rather than on the economic value of MPA which is more informative for management purposes. In the case of ecological effects, a number of indicators could be identified and some assessed. These indicators are not specific to MPAs nor to coral reef ecosystems, and cover ecological assessment in general. Their effectiveness could be assessed for some, showing in particular that the most widely used ones were not necessarily the most efficient (e.g. density at the species or genus level). A number of expected ecological effects have never been really tested (e.g. effects on recruitment, on habitat quality, genetic effects) or too rarely so that the performance of corresponding metrics cannot be assessed. Note that several metrics were not found relevant according to our definition, but may still prove interesting in the future. This analysis should be regarded as a first attempt to score indicators in a meta-analysis approach.

The review of both ecological and economic articles reasserts the need for assessments that take into account the evolution of the ecosystem and its uses in the absence of MPA, referred to as Before/After Control Impacts designs in ecology. Another parallel between ecological and economic studies comes from the need for integrated assessments, referred to as total value analysis in the economic field. Most studies tackle one or two effects of MPA, but never address effects at the system scale, whether the ecosystem, the fishery, or the coastal ecosystem together with its uses. In this domain, perspectives include i) integrated modeling that is in addition needed for constructing indicators of system dynamics; and ii) joint panels of complementary indicators that address different MPA-related effects.

As for ecological effects, the present review shows a striking discrepancy between all the advocated (mostly positive) effects on one hand, and on the other hand, the number of effects that are not studied, or tested through metrics with low effectiveness. This brings us to first conclude that there is an avenue for new empirical studies with rigorous experimental designs. The sources of variability inherent in natural systems make it more difficult to devise and implement efficient designs and to set up indicators that account for these uncertainties. The goal of constructing statistically sound indicators useful for managers might be a good incentive in this respect. Russ (2002) also stressed that "there is a plethora of reviews on what marine reserves could do as a fisheries management tools, and yet there is a distinct paucity of empirical studies demonstrating what they can do"; Willis et al. (2003b) share the same opinion. Our review provides quantifications for these considerations, and shows in addition that they also apply for economic and social effects of MPA. Hence, it would be useful to devote more resources for effective monitoring of ecological, economic and social effects related to established MPAs.

A corollary to this conclusion pertains to the boom in MPA creations, with publicized optimistic views on their positive consequences, even on the short-term. As stressed by Agardy et al. (2003) "... the tendency to decree as many MPAs as possible, an eagerness to do so without a clear understanding of many of the complexities or balanced framework required ... may inadvertently impede success". We believe that a closer collaboration with managers would be necessary to anticipate and monitor MPA effects. Investigations of social effects of MPA are particularly needed, because MPAs may be biological successes but social failures (Christie 2004). Therefore, indicators for both ecological, economic and social effects are jointly needed for MPA assessment. Projects aimed at devising ecological, economic and social indicators that are both scientifically grounded and useful for managers seem good opportunities for such collaborations.

Acknowledgements. This work was made possible through a grant of the "Programme National de l'Environnement Côtier (PNEC)", "Action de Recherche Thématique 4" and "Chantier NouvelleCalédonie". We gratefully acknowledge Patrick Christie and an anonymous reviewer for stimulating suggestions on the first version of the paper.

\section{References}

Agardy T., 2000, Effects of fisheries on marine ecosystems: A conservationist's perspective. ICES J. Mar. Sci. 57, 761-765.

Agardy T., Bridgewater P., Crosby M.P., Day J.W., Dayton P.K., Kenchington R., Laffoley D., McConney P., Murray P.A., Parks J.E., Peau L., 2003, Dangerous targets? Unresolved issues and ideological clashes around marine protected areas. Aquat. Conserv. Mar. Freshwater Ecosyst. 13, 353-367.

Alcala A.C., 1988, Effects of marine reserves on coral fish abundances and yields of Philippine coral reefs. Ambio 17, 194-199.

Alcala A.C., Russ G.R., 1990, A direct test of the effects of protective management on abundance and yield of tropical marine resources. J. Cons. Int. Explor. Mer 46, 40-47.

Alder J., 1996, Have tropical marine protected areas worked? An initial analysis of their success. Coast. Manage. 24, 97-114.

Allison G.W., Lubchenko J., Carr M.H., 1998, Marine reserves are necessary but not sufficient for marine conservation. Ecol. Appl. 8, S79-S92.

Anderson L.G., 2002, A bioeconomic analysis of marine reserves. Nat. Resour. Modeling 15, 311-334. 
Arias-Gonzales J.E., 1998, Trophic models of protected and unprotected coral reef ecosystems in the South of the Mexican Carribean. J. Fish Biol. 53 (Suppl. A), 236-255.

Arin T., Kramer R.A., 2002, Divers' willingness to pay visit marine sanctuaries: an exploratory study. Ocean Coast. Manage. 45, 171-183.

Armstrong D.A., Wainwright T.C., Jensen G.C., Dinnel P.A., Andersen H.B., 1993, Taking refuge from bycatch issues: Red king crab (Paralithodes camtschaticus) and trawl fisheries in the eastern Bering Sea. Can. J. Fish. Aquat. Sci. 50, 1993-2000.

Attwood C.G., Bennett B.A., 1994, Variation in dispersal of Galjoen (Coracinus capensis) (Teleostei: Coracinidae) from a marine reserve. Can. J. Fish. Aquat. Sci. 51, 1247-1257.

Babcock R.C., Kelly S., Shears N.T., Walker J.W., Willis T.J., 1999, Changes in community structure in temperate marine reserves. Mar. Ecol. Prog. Ser. 189, 125-134.

Badalamenti F., Ramos A.A., Voultsiadou E., Sánchez-Lizaso J.L., D'Anna G., Pipitone C., Mas J., Ruiz Fernandez J.A., Whitmarsh D., Riggio S., 2000, Cultural and socio-economic impacts of Mediterranean protected areas. Environ. Conserv. 27, 110-125.

Bell J.D., 1983, Effects of depth and marine reserve fishing restrictions on the structure of a rocky reef fish assemblage in the Northwestern Mediterranean sea. J. Appl. Ecol. 20, 357-369.

Béné C., Tewfik A., 2003, Biological evaluation of marine protected area: Evidence of crowding effect on a protected population of queen conch in the Caribbean. PSZNI Mar. Ecol. 24, 45-58.

Bennett B.A., Attwood C.G., 1991, Evidence for recovery of a surfzone fish assemblage following the establishment of a marine reserve on the southern coast of South Africa. Mar. Ecol. Prog. Ser. 75, 173-181.

Bhat M.G., 2003, Application of non-market valuation to the Florida Keys marine reserve management. J. Environ. Manage. 67, 315-325.

Bjorndal K.A., Wetherall J.A., Bolten A.B., Mortimer J.A., 1999, Twenty-six years of green turtle nesting at Tortuguero, Costa Rica: An encouraging trend. Conserv. Biol. 13, 126-134.

Boersma D.P., Parrish J.K., 1999, Limiting abuse: Marine protected areas, a limited solution. 31, 287-304.

Bohnsack J.A., 1996, Marine reserves, zoning, and the future of fishery management. Fisheries 21, 14-16.

Boncoeur J., Alban F., Guyader O., Thébaud O., 2002, Fish, fishers, seals and tourists: Economic consequences of creating a marine reserve in a multi-species, multi-activity context. Nat. Resour. Modeling 15, 387-411.

Brown K., Adger W.N., Tompkins E., Bacon P., Shim D., Young K., 2001, Trade-off analysis for marine protected area management. Ecol. Econ. 37, 417-434.

Bryant D., Burke L., McManus J., Spalding. M., 1998, Reefs at risk: A map-based indicator of threats to the world's coral reefs. World Resource Institute, Washington DC.

Buxton C.D., 1993, Life-history changes in exploited reef fishes on the east coast of South Africa. Environ. Biol. Fish. 36, 47-63.

Buxton C.D., Allen J.A., 1989, Mark and recapture studies of two reef sparids in the Tsisikamma National Park. Koedoe 32, 39-45.

Buxton C.D., Smale M.J., 1989, Abundance and distribution patterns of three temperate marine reef fish (Teleostei: Sparidae) in exploited and unexploited areas off the southern Cape coast. J. Appl. Ecol. 26, 441-451.

Carter D.W., 2003, Protected areas in marine resource management: Another look at the economics and research issues. Ocean Coast. Manage. 46, 439-456.
Castilla J.C., Bustamante R.H., 1989, Human exclusion from rocky intertidal of Las Cruces, central Chile: Effects on Durvillaea antartica (Phaeophyta, Durvilleales). Mar. Ecol. Prog. Ser. 50, 203-214.

Cesar H., 1996, Economic analysis of Indonesian coral reefs. Environment Department Paper. World Bank.

http://lnweb18. worldbank.org/ESSD/essdext.nsf/ 44DocByUnid/623623.

Cesar H., 2002, The biodiversity benefits of coral reef ecosystems: Values and markets, Organisation de Coopération et de Développement Economiques, Paris.

Cesar H., Burke L., Pet-Soede L., 2003, The economics of worldwide coral reef degradation. CEEC, Arnhem.

Chapman M.R., Kramer D.L., 1999, Gradients in coral reef fish density and size across the Barbados marine reserve boundary: Effects of reserve protection and habitat characteristics. Mar. Ecol. Prog. Ser. 181, 81-96.

Chapman M.R., Kramer D.L., 2000, Movements of fishes within and among fringing coral reefs in Barbados. Environ. Biol. Fish. 57, 11-24.

Chiappone M., Sealey K.M., 2000, Marine reserve design criteria and measures of success: Lessons learned from the Exuma Cays land and sea park, Bahamas. Bull. Mar. Sci. 66, 691-705.

Chiappone M., Sluka R., Sealey S., 2000, Groupers (Pisces: Serranidae) in fished and protected areas of the Florida Keys, Bahamas and northern Caribbean. Mar. Ecol. Prog. Ser. 198, 261-272.

Christie P., 2004, Marine protected areas as biological successes and social failures in Southeast Asia. Am. Fish. Soc. Symp., in press.

Christie P., White A., Deguit E., 2002, Starting point or solution? Community-based marine protected areas in the Philippines. J. Environ. Manage. 66, 441-454.

Ciriaco S., Costantini M., Italiano C., Odorico R., Picciulin M., Verginella L., Spoto M., 1998, Monitoring the Miramare marine reserve: Assessment of protection efficiency. Ital. J. Zool. 65, 383-386.

Claudet J., Pelletier D., 2004, Marine protected areas and artificial reefs: A review of the interactions between management and scientific studies. Aquat. Living Resour. 17, 129-138.

Clifton J., 2003, Prospects for co-management in Indonesia's marine protected areas. Mar. Pol. 27, 389-395.

Cocklin C., Craw M., McCauley I., 1998, Marine reserves in New Zealand: Use rights, public attitudes, and social impacts. Coast. Manage. 26, 213-231.

Cole R.G., Ayling T.M., Creese R.G., 1990, Effects of marine reserve protection at Goat Island, northern New Zealand. New Zealand J. Mar. Freshwater Res. 16, 233-250.

Conover D.O., Travis J., Coleman F.C., 2000, Essential fish habitat and marine reserves: An introduction to the second Mote symposium in fisheries ecology. Bull. Mar. Sci. 66, 527-534.

Conrad J.M., 1999, The bioeconomics of marine sanctuaries. J. Bioecon. 1, 205-217.

Crosby M.P., 1994, A proposed approach for studying ecological and socio-economic impacts of alternative access management strategies for marine protected areas. In: D. Brunckhorst (Eds.), Marine protected areas and biosphere reserves: Towards a new paradigm, Australian Nature Conservation Agency, Canberra, pp. 45-65.

Crosby M.P., Brighouse G., Pichon M., 2002, Priorities and strategies for addressing natural and anthropogenic threats to coral reefs in Pacific Island Nations. Ocean Coast. Manage. 45, 121-137.

Crowder L.B., Lyman S.J., Figueira W.F., Priddy J., 2000, Sourcesink population dynamics and the problem of siting marine reserves. Bull. Mar. Sci. 66, 799-820. 
David G., 1998, Protected areas in tropical countries, and development cooperation, In G. Rossi (eds), II ${ }^{\mathrm{es}}$ Rencontres Dynamiques Sociales et Environnement, pour un dialogue entre chercheurs, opérateurs et bailleurs de fonds, UMRREGARDS/GRET CNRS-Orstom, Bordeaux, 2, pp. 361-367.

Davis D., Tisdell C., 1995, Recreational scuba-diving and carrying capacity in marine protected areas. Ocean Coast. Manage. 26, 19-40.

Davis D., Tisdell C., 1996, Economic management of recreational scuba diving and the environment. J. Environ. Manage. 48, 229-248.

Davis G.E., 1977, Effects of recreational harvest on a spiny loster, Panulirus argus, population. Bull. Mar. Sci. 27, 223-236.

Davis G.E., Dodrill J.W., 1989, Recreational fishery and population dynamics of spiny lobsters, Panulirus argus, in Florida Bay, Everglades National Park, 1977-1980. Bull. Mar. Sci. 44, 78-88.

Day J.C., 2002, Zoning lessons from the Great Barrier Reef Marine Park. Ocean Coast. Manage. 45, 139-156.

Denny C.M., Babcock R.C., 2004, Do partial marine reserves protect fish assemblages. Biol. Conserv. 116, 119-129.

Dixon J.A., 1993, Economic benefits of marine protected areas. Oceanus 36, 35-40.

Dixon J.A., Scura L.F., van't Hof T., 1993, Meeting ecological and economic goals: marine parks in the Caribbean. Ambio 22, $117-125$.

Dufour V., Jouvenel J.Y., Galzin R., 1995, Study of a Mediterranean fish assemblage. Comparisons of population distributions between depths on protected and unprotected areas over one decade. Aquat. Living Resour. 8, 17-25.

Dugan J.E., Davis G.E., 1993, Introduction to the international symposium on marine harvest refugia. Can. J. Fish. Aquat. Sci. 50, 1991-1992.

Dulvy N.K., Mitchell R.E., Watson D., Sweeting C.J., Polunin N.V.C., 2002, Scale-dependent control of motile epifaunal community structure along a coral reef fishing gradient. J. Exp. Mar. Biol. Ecol. 278, 1-29.

Edgar G.J., Barrett N.S., 1997, Short term monitoring of biotic change in Tasmanian marine reserves. J. Exp. Mar. Biol. Ecol. 213, 261-279.

Edgar G.J., Barrett N.S., 1999, Effects of the declaration of marine reserves on Tasmanian reef fishes, invertebrates and plants. J. Exp. Mar. Biol. Ecol. 242, 107-144.

Elliot G., Mitchell B., Wiltshire B., Manan I., Wismer S., 2001, Community participation in marine protected area management: Wakatobi National Park, Sulawesi, Indonesia. Coast. Manage. 29, 295-316.

Engel J., Kvitek R., 1998, Effects of otter trawling on a benthic community in Monterey Bay National Marine Sanctuary. Conserv. Biol. 12, 1204-1214.

Epstein N., Bak R.P.M., Rinkevitch B., 1999, Implementation of a small-scale "no-use zone" policy in a reef ecosystem: Eilat's reeflagoon six years later. Coral Reefs 18, 327-332.

Eristhee N., Oxenford H.A., 2001, Home range size and use of space by Bermuda chub Kyphosus sectatrix (L.) in two marine reserves in the Soufrière Marine Management Area, St Lucia, West Indies. J. Fish Biol. 59, 129-151.

Farrow S., 1996, Marine protected areas: Emerging economics. Mar. Pol. 20, 439-446.

Ferraris J., Beliaeff B., Galzin R., Perez T., 2005, Indicators in reef ecosystems. Aquat. Living Resour. 18.

Ferreira B.P., Russ G.R., 1995, Population structure of the leopard coralgrouper, Plectropomus leopardus, of fished and unfished reefs off Townsville, Central Great Barrier Reef, Australia. Fish. Bull. 93, 629-642.
Fiske S.J., 1992, Socio-cultural aspects of establishing marine protected areas. Ocean Shoreline Manage. 18, 25-46.

Francour P., 1994, Pluriannual analysis of the reserve effect on ichthyofauna in the Scandola natural reserve (Corsica, Northwestern Mediterranean). Oceanol. Acta 17, 309-317.

Francour P., 2000, Evolution spatio-temporelle à long terme des peuplements de poissons des herbiers à Posidonia oceanica de la réserve naturelle de Scandola (Corse, Méditerranée nordoccidentale). Cybium 24, 85-95.

Frank K.T., Shackell N.L., Simon J.E., 2000, An evaluation of the Emerald/Western Bank juvenile haddock closed area. ICES J. Mar. Sci. 57, 1023-1034.

García-Charton J.A., Pérez-Ruzafa A., 1999, Ecological heterogeneity and the evaluation of the effects of marine reserves. Fish. Res. 42, 1-20.

García-Charton J.A., Pérez-Ruzafa A., Sánchez-Jerez P., Bayle-Sempere J.T., Reñones O., Moreno D., 2004, Multi-scale spatial heterogeneity, habitat structure, and the effect of marine reserves on Western Mediterranean rocky reef fish assemblages. Mar. Biol. 144, 161-182.

García-Charton J.A., Williams I.D., Pérez-Ruzafa A., Milazzo M., Chemello R., Marcos C., Kitsos M.S., Koukouras A., Riggio S., 2000, Evaluating the ecological effects of Mediterranean protected areas: Habitat, scale and the natural variability of ecosystems. Environ. Conserv. 27, 159-178.

García-Rubies A.G., Zabala M., 1990, Effects of total fishing prohibition on the rocky fish assemblages of Medes Islands marine reserve (Mediterranean). Scient. Mar. 54, 317-328.

Geen G., Lal P., 1991, Charging users of the Great barrier Reef Marine Park., ABARE, Canberra.

Gitschlag G.R., 1986, Movement of pink shrimp in relation to the Tortugas sanctuary. N. Am. J. Fish. Manage. 6, 328-338.

Gustavson K., Lonergan S.C., Ruitenbeck J., 2002, Measuring contributions to economic production - use of an index of captured ecosystem value. Ecol. Econ. 41, 479-490.

Halpern B., 2003, The impact of marine reserves: Do reserves work and does reserve size matter? Ecol. Appl. 13, S117-S137.

Hannesson R., 1998, Marine reserves: What would they accomplish? Mar. Resour. Econ. 13, 159-170.

Hannesson R., 2002, The economics of marine reserves. Nat. Resour. Model. 15, 273-290.

Harmelin J.G., Bachet F., Garcia F., 1995, Mediterranean marine reserves: Fish indices as tests of protection efficiency. PSZNI Mar. Ecol. 16, 233-250.

Hoagland P., Kaoru Y., Broadus J., 1995, A methodological review of net benefit evaluation for marine reserves. Environment Department Papers, 27, World Bank.

Hodgson G., Dixon J.A., 1992, Sedimentation damage to marine resources: Environmental and economic analysis. In: J.B. Marsh (Eds.), Resources and environment in Asia's marine sector. Taylor \& Francis, London, 421-445.

Hoffmann E., Dolmer P., 2000, Effect of closed areas on distribution of fish and epibenthos. ICES J. Mar Sci. 57, 1310-1314.

Holland D.S., 2000, A bioeconomic model of marine sanctuaries on Georges Bank. Can. J. Fish. Aquat. Sci. 57, 1307-1319.

Holland D.S., Brazee R.J., 1996, Marine reserves for fisheries management. Mar. Resour. Econ. 11, 157-171.

Holland K.N., Lowe C.G., Wetherbee B.M., 1993, Movements and dispersal patterns of blue trevally (Caranx melanpygus) in a fisheries conservation zone. Fish. Res. 25, 279-292.

Holmlund C.M., Hammer M., 1999, Ecosystem services generated by fish populations. Ecol. Econ. 29, 253-268. 
Jameson S.C., Ammar M.S.A., Saadalla E., Mostafa H.M., Riegl B., 1999, A coral damage index and its application to diving sites in the Egyptian Red Sea. Coral Reefs 18, 333-339.

Jennings S., Grandcourt E.M., Polunin N.V.C., 1995, The effects of fishing on the diversity, biomass and trophic structure of Seychelles' reef fish communities. Coral Reefs 14, 225-235.

Jennings S., Marshall S.S., Polunin N.V.C., 1996, Seychelles' protected areas: Comparative structure and status of reef fish communities. Biol. Conserv. 75, 201-209.

Johnson D.R., Funicelli N.A., Bohnsack J.A., 1999, Effectiveness of an existing estuarine no-take fish sanctuary within the Kennedy space center, Florida. N. Am. J. Fish. Manage. 19, 436-453.

Jones G.P., Cole R.C., Battershill C.N., 1992, Marine reserves: do they work? In: C.N. Battershill, D.R. Schiel, G.P. Jones, R.G. Creese, A.B. MacDiarmid (Eds.), Proceedings 2nd International Temperate Reef Symposium, NIWA Marine, Wellington, pp. 29-45.

Jones G.P., Milicich M.J., Emslie M.J., Lunow C., 1999, Self-recruitment in a coral reef fish population. Nature 402, 802-804.

Jouvenel J.Y., Pollard D.A., 2001, Some effects of marine reserve protection on the population structure of two spearfishing targetfish species, Dicentrarchus labrax (Moronidae) and Sparus aurata (Sparidae), in shallow inshore waters, along a rocky coast in the northwestern Mediterranean Sea. Aquat. Conserv. Mar. Freshwater Ecosyst. 11, 1-9.

Kelleher G., Bleakley C., Wells S., 1995, A global representative system of marine protected areas, Vol. 1. 10/03, The World Bank.

Kelleher G., Kenchington R., 1992, Guidelines for establishing marine protected areas, IUCN, Gland, Suisse.

Kelly S., Scott D., McDiarmid A.B., Babcock R.C., 2000, Spiny lobster, Jasus edwardsii, recovery in New Zealand marine reserves. Biol. Conserv. 92, 359-369.

Kenchington R., 1991, Tourism development in the Great Barrier Reef marine park. Ocean Shoreline Manage. 15, 57-78.

Kenchington R., 1993, Tourism in coastal and marine environments A recreational perspective. Ocean Coast. Manage. 19, 1-16.

Kruse G.H., Bez N., Booth T., Dorn M., Hills S., Lipcius R., Pelletier D., Roy C., Smith S.S.W., 2001, Spatial Processes and Management of Marine Populations., University of Alaska Sea Grant, AK-SG-00-04, Fairbanks, Anchorage.

La Mesa G., Vacchi M., 1999, An analysis of the coastal fish assemblage of the Ustica island Marine Reserve (Mediterranean Sea). PSZNI Mar. Ecol. 20, 147-165.

Lauck T., Clark C.W., Mangel M., Munro G.R., 1998, Implementing the precautionary principle in fisheries management through the implementation of marine reserves. Ecol. Appl. 8, 572-578.

Ledoux L., R.K. Turner, 2002, Valuing ocean and coastal resources: A review of practical examples and issues for further action. Ocean Coast. Manage. 45, 583-616.

Leeworthy V.R., 1991, Recreational use value for John Pennekamp Coral Reef State Park and Key Largo National Marine Sanctuary. Strategic Environmental Assessment Division Report, NOAA.

Letourneur Y., 1996, Réponse des peuplements et populations de poissons aux réserves marines : Le cas de l'île de Mayotte, Océan Indien occidental. Ecoscience 3, 442-450.

Lipton D.W., Wellman K.F., 1995, Economic valuation of natural resources: A handbook for coastal resource policymakers. Decision Analysis Series, 5, NOAA/Coastal Ocean Program.

MacPherson E., Biagi F., Francour P., García-Rubies A., Harmelin J., Harmelin-Vivien M.-L., Jouvenel J.Y., Planes S., Vigliola L., Tunesi L., 1997, Mortality of juvenile fishes of the genus Diplodus in protected and unprotected areas in the western Mediterranean Sea. Mar. Ecol. Prog. Ser. 160, 135-147.
MacPherson E., Gordoa A., García-Rubies A., 2002, Biomass size spectra in littoral fishes in protected and unprotected areas in the NW Mediterranean. Estuar. Coast. Shelf Sci. 55, 777-788.

McAllister D.E., 1988, Environmental, economic and social costs of coral reef destruction in the Philippines. Galaxea 7, 161-178.

McClanahan T.R., 1994, Kenyan coral reef lagoon fish: effects of fishing, substrate complexity, and sea urchins. Coral Reefs 13, 231-241.

McClanahan T.R., 2000, Recovery of a coral reef keystone predator, Balistapus undulatus, in East African marine parks. Biol. Conserv. 94, 191-198.

McClanahan T.R., Kaunda-Arara B., 1996, Fishery recovery in a coral-reef marine park and its effect on the adjacent fishery. Conserv. Biol. 10, 1187-1199.

McClanahan T.R., Mangi S., 2000, Spillover of exploitable fishes from a marine park and its effect on the adjacent fishery. Ecol. Appl. 10, 1792-1805.

McClanahan T.R., McField M., Huitric M., Bergman K., Sala E., Nyström M., Nordemar I., Elfwing T., Muthiga N.A., 2001, Responses of algae, corals and fish to the reduction of macroalgae in fished and unfished patch reefs of Glovers Reef Atoll, Belize. Coral Reefs 19, 367-379.

McClanahan T.R., Muthiga N.A., 1988, Changes in Kenyan coral reef community structure and function due to exploitation. Hydrobiologia 166, 269-276.

McClanahan T.R., Muthiga N.A., Kamukuru A.T., Machano H., Kiambo R.W., 1999, The effects of marine parks and fishing on coral reefs of northern Tanzania. Biol. Conserv. 89, 161-182.

Medley P.A., Gaudian G., Wells S., 1993, Coral reef fisheries stock assessment. Rev. Fish Biol. Fish. 3, 242-285.

Meganck R.A., 1991, Coastal parks as development catalysts: a Caribbean example. Ocean Shoreline Manage. 15, 25-36.

Meyer C.G., Holland K.N., Wetherbee B.M., Lowe C.G., 2000, Movement patterns, habitat utilization, home range size and site fidelity of whitesaddle goatfish, Parupeneus porphyreus, in a marine reserve. Environ. Biol. Fishes 59, 235-242.

Milazzo M., Chemello R., Badalamenti F., Riggio S., 2002, Short-term effect of human trampling on the upper infralittoral macroalgae of Ustica Island MPA (western Mediterranean, Italy). J. Mar. Biol. Assoc. UK 82, 745-748.

Millar R.B., Willis T.J., 1999, Estimating the relative density of snapper in and around a marine reserve using a log-linear mixedeffects model. Aust. N.Z. J. Statist. 41, 383-394.

Moberg F., Folke C., 1999, Ecological goods and services of coral reef ecosystems. Ecol. Econ. 29, 215-233.

Moberg F., Rönnbäck P., 2003, Ecosystem services of the tropical seascape: Interactions, substitutions and restoration. Ocean Coast. Manage. 46, 27-46.

National Research Council, 2001, Marine Protected Areas: Tools for sustaining ocean ecosystems. Committee on the Evaluation, Design, and Monitoring of Marine Reserves and Protected Areas in the United States, National Academy of Sciences, Washington DC.

Paddack M.J., Estes J.A., 2000, Kelp forest fish populations in marine reserves and adjacent exploited areas of central California. Ecol. Appl. 10, 855-870.

Pendleton L.H., 1995, Valuing coral reef protection. Ocean Coast. Manage. 26, 119-130.

Pezzey J.C.V., Roberts C.M., Urdal B.T., 2000, A simple bioeconomic model of a marine reserve. Ecol. Econ. 33, 77-91.

Piet G.J., Rijnsdorp A.D., 1998, Changes in the demersal fish assemblage in the south-eastern North Sea following the establishment of a protected area ("plaice box"). ICES J. Mar. Sci. 55, 420-429. 
Pinnegar J.K., Polunin N.V.C., Francour P., Badalamenti F., Chemello R., Harmelin-Vivien M.-L., Hereu B., Milazzo M., Zabala M., D'Anna G., Pipitone C., 2000, Trophic cascades in benthic marine ecosystems: Lessons for fisheries and protected-area management. Environ. Conserv. 27, 179-200.

Plan Development Team, 1990, The potential of marine fishery reserves for reef fish management in the U.S. Southern Atlantic. Technical Memorandum, NMFS-SEFC 261, NOAA.

Planes S., Galzin R., Garcìa-Rubies A., Goñi R., Harmelin J.-G., Le Diréach L., Lenfant P., Quetglas A., 2000, Effects of marine protected areas on recruitment processes with special reference to Mediterranean littoral ecosystems. Environ. Conserv. 27, 126-143.

Pollnac R.B., Crawford B.B., Goroscope M.L.G., 2001, Discovering factors that influence the success of community-based marine protected areas in the Visayas, Philippines. Ocean Coast. Manage. 44, 683-710.

Polunin N.V.C., Roberts C.M., 1993, Greater biomass and value of target coral-reef fishes in two small Caribbean marine reserves. $100,167-176$.

Polunin N.V.C.e., 2000, Papers from the ECOMARE project. Environ. Conserv. 27, 95-200.

Price A.R.G., Humphrey S.L., 1993, Application of the Biosphere Reserve concept to coastal marine areas. A Marine Conservation and Development Report, IUCN.

Rakitin A., Kramer D.L., 1996, Effect of a marine reserve on the distribution of coral reef fishes in Barbados. Mar. Ecol. Prog. Ser. 131, 97-113.

Roberts C.M., 1995, Rapid build-up of fish biomass in a Caribbean marine reserve. Conserv. Biol. 9, 815-826.

Roberts C.M., Bohnsack J.A., Gell F., Hawkins J.P., Goodridge R., 2001, Effects of marine reserves on adjacent fisheries. Science 294, 1920-1923.

Roberts C.M., Hawkins J.P., 2000, Fully-protected marine reserves: A guide. WWF Endangered seas caMPAign. http://www . panda.org/resources/publications/ water/mpreserves/mar_dwnld.htm.

Roberts C.M., Polunin N.V.C., 1991, Are marine reserves effective in management of reef fisheries? Rev. Fish Biol. Fish. 1, 65-91.

Roberts C.M., Polunin N.V.C., Year. Effects of marine reserve protection on Northern Red Sea fish populations. Proceedings of the Seventh International Coral Reef Symposium, Guam, 969-977.

Roberts C.M., Polunin N.V.C., 1993, Marine reserves: Simple solutions to managing complex fisheries. Ambio 22, 363-368.

Roberts C.M., Sargant H., Year. Fishery benefits of fully protected marine reserves: Why habitat and behavior are important. Economics of Marine Protected Areas, Vancouver, University of British Columbia, 9, 171-182.

Rodwell L.D., Barbier E.B., Roberts C.M., McClanahan T.R., Year. A model of tropical marine reserve - Fishery linkages. Economics of Marine Protected Areas, University of British Columbia, 15, 183-197.

Rouphael A.B., Inglis G.J., 2001, "Take only photographs and leave only footprints?" An experimental study of the impacts of underwater photographers in a coral reef dive site. Biol. Conserv. 100, 281-287.

Rowe S., 2002, Population parameters of American lobster inside and outside no-take reserves in Bonavista Bay, Newfoundland. Fish. Res. 56, 167-175.

Rowley R.J., 1994, Marine reserves in fisheries management. Aquat. Conserv. 4, 233-254.

Rudd M.A., Tupper M.H., Folmer H., van Kooten G.C., 2003, Policy analysis for tropical marine reserves: Challenges and directions. Fish Fish. 4, 65-85.
Ruddle K., 1989, Traditional sole property rights and modern inshore fisheries management in the Pacific basin. Economics of fishery management in the Pacific Islands region, ACIAR Proceedings, $26,68-76$.

Ruddle K., Johannes R.E., 1990, Traditional marine resource management in the Pacific basin: An anthology, UNESCO, Jakarta.

Russ G.R., Year. Effects of protective management on coral reef fishes in the Central Philippines. Proc. 5th Int. Coral Reef Symp., Tahiti, 4, 219-224.

Russ G.R., 1991, Coral reefs fisheries: Effects and yields. In: Sale P.F. (Eds.), The ecology of fishes on coral reefs, Academic Press, London, pp. 601-637.

Russ G.R., 2002, Yet another review of marine reserves as reef fishery management tools, In: Sale P.F. (Eds.), Coral reef fishes: Dynamics and diversity in a complex ecosystem, Academic Press, London, pp. 421-443.

Russ G.R., Alcala A.C., 1989, Effects of intense fishing pressure on an assemblage of coral reef fishes. Mar. Ecol. Prog. Ser. 56, 13-27.

Russ G.R., Alcala A.C., 1996a, Do marine reserves export adult fish biomass? Evidence from Apo island, central Philippines. Mar. Ecol. Prog. Ser. 132, 1-9.

Russ G.R., Alcala A.C., 1996b, Marine reserves: Rates and patterns of recovery and decline of large predatory fish. Ecol. Appl. 6, 947-961.

Russ G.R., Alcala A.C., 1998a, Natural fishing experiments in marine reserves 1983-1993: Community and trophic responses. Coral Reefs 17, 383-397.

Russ G.R., Alcala A.C., 1998b, Natural fishing experiments in marine reserves 1983-1993: Role of life history and fishing intensity in family responses. Coral Reefs 17, 399-416.

Russ G.R., Alcala A.C., 1999, Management histories of Sumilon and Apo marine reserves, Philippines, and their influence on national marine resource policy. Coral Reefs 18, 307-319.

Sale P.F., 2002, Coral reef fishes, Elsevier Science.

Salm R.V., Clark J.R., Siirila E., 2000, Marine and coastal protected areas: A guide for planners and managers, IUCN.

Salvat B., Haapkylä J., Schrimm M., 2002, Coral reef protected areas in international instruments, Man and Biosphere Programme, UNESCO.

Sánchez-Jerez P., García-Charton J.A., Bayle-Sempere J., Pérez-Ruzafa A., Ramos-Espla A.A., Year. Comparing the abundance of fish populations and assemblages by visual counts: problems with sampling design and analyses. International workshop on fish visual censuses in marine protected areas, Ustica, Italy, 26-27 June 1997,

Sánchez-Lizaso J.L., Goni R., Reñones O., García-Charton J.A., Galzin R., Bayle J.T., Sánchez-Jerez P., Pérez-Ruzafa A., Ramos A.A., 2000, Density dependence in marine protected populations: A review. Environ. Conserv. 27, 144-158.

Sanchirico J., Wilen J., 2002, The impacts of marine reserves on limited-entry fisheries. Nat. Resour. Model. 15, 291-310.

Sanchirico J.N., Wilen J.E., 2001, A bioeconomic model of marine reserve creation. J. Environ. Econ. Manage. 42, 257-276.

Sant M., 1996, Environmental sustainability and the public: Responses to a proposed marine reserve at Jervis Bay, New South Wales, Australia. Ocean Coast. Manage. 32, 1-16.

Sasal P., Faliex E., Morand S., 1996, Parasitism of Gobius buchichii Steindachner, 1870 (Teleostei, Gobiidae) in protected and unprotected marine environments. J. Wildl. Dis. 32, 607-613.

Scholz A., Bonzon K., Fujita R., Benjamin N., Woodling N., Black P., Steinback C., 2004, Participatory socioeconomic analysis: Drawing on fishermen's knowledge for marine protected area planning in California. Mar. Pol. 28, 335-349. 
Shafer C.S., Benzaken D., 1998, User perceptions about wilderness on Australia's Great Barrier Reef. Coast. Manage. 26, 79-91.

Shears N.T., Babcock R.C., 2002, Marine reserves demonstrate top-down control of community structure on temperate reefs. Oecologia 132, 131-142.

Shears N.T., Babcock R.C., 2003, Continuing trophic cascade effects after 25 years of no-take marine reserve protection. Mar. Ecol. Prog. Ser. 246, 1-16.

Silva M.E., Gately E.M., Desilvestre I., 1986, A bibliographic listing of coastal and marine protected areas: A global survey. Technical Report, WHOI-86-11, Woodshole Oceanographic Institute.

Sluka R., Chiappone M., Sullivan K.M., Wright R., Year. The benefits of a marine fishery reserve for Nassau grouper Epinephelus striatus in the central Bahamas. Proceedings of the Eigth International Coral Reef Symposium, Panama, 2, 1961-1964.

Sobel J., 1993, Conserving biological diversity through marine protected areas. Oceanus 36, 19-26.

Spash C., van den Werff T., Bosch J.D., Westmacott S., Ruitenbeek H.J., 1998, Lexicographic preferences and the contingent valuation of coral reef biodiversity in Curacao and Jamaica. Resource Analysis Report, pp. 98-327, World Bank.

Spurgeon J.P.G., 1992, The economic valuation of coral reefs. Mar. Pollut. Bull. 11, 529-536.

Stoner A.W., Ray M., 1996, Queen conch, Strombus gigas, in fished and unfished locations in the Bahamas: Effects of a marine fishery reserve on adults, juveniles, and larval production. Fish. Bull. 94, 551-565.

Sumaila U.R., Alder J., 2001, Economic of marine protected areas. University of British Columbia.

Sumaila U.R., Charles A.T., 2002, Economic models of marine protected areas: An introduction. Nat. Resour. Modeling 15, 261272.

Suman D., Shivlani M., Milon J.W., 1999, Perceptions and attitudes regarding marine reserves: A comparison of stakeholder groups in the Florida Keys Marine Sanctuary. Ocean Coast. Manage. 42, 1019-1040.

Talbot F.H., 1994, Coral reef protected areas: what are they worth? In D. Brunckhorst (eds), Marine protected areas and biosphere reserves: towards a new paradigm, Australian Nature Conservation Agency, Canberra, pp. 40-44.

Thorrold S.R., Latkoczy C., Swart P.K., Jones C.M., 2001, Natal homing in a marine fish metapopulation. Science 291, 297-299.

Tratalos J.A., Austin T.J., 2001, Impacts of recreational SCUBA diving on coral communities of the Carribean island of Gran Cayman. Biol. Conserv. 102, 67-75.

Turner R.K., Adger W.N., 1996, Coastal zone resources assessment guidelines. 4, LOICZ Core Project - Netherlands Institute for Sea Research.

Tuya F.C., Soboil M.L., Kido J., 2000, An assessment of the effectiveness of marine protected areas in the San Juan Islands, Washington, USA. ICES J. Mar. Sci. 57, 1218-1226.
Valles H., Sponaugle S., Oxenford H.A., 2001, Larval supply to a marine reserve and adjacent fished area in the Soufrière Marine Management Area, St Lucia, West Indies. J. Fish Biol. 59, 152-177.

Wallace S.S., 1999, Evaluating the effects of three forms of marine reserve on northern abalone populations in British Columbia, Canada. Conserv. Biol. 13, 882-887.

Wantiez L., Thollot P., Kulbicki M., 1997, Effects of marine reserves on coral reef fish communities from five islands in New Caledonia. Coral Reefs 16, 215-224.

Watson M., Righton D., Austin T., Ormond R., 1996, The effects of fishing on coral reef fish abundance and diversity. J. Mar. Biol. Assoc. UK 76, 229-233.

Westera M., Mavery P., Hyndes G., 2003, Differences in recreationally targeted fishes between protected and fished areas of a coral reef marine park. J. Exp. Mar. Biol. Ecol. 294, 145-168.

Willis T.J., D.M. P., Babcock R.C., 2001, Evidence for site fidelity of snapper (Pagrus auratus) within a marine reserve. N.Z.. J. Mar. Freshwater Res. 35, 581-590.

Willis T.J., Millar R.B., Babcock R.C., 2003a, Protection of exploited fish in temperate regions: High density and biomass of snapper Pagrus auratus (Sparidae) in northern New Zealand marine reserves. J. Appl. Ecol. 40, 214-227.

Willis T.J., Millar R.B., Babcock R.C., Tolimieri N., 2003b, Burdens of evidence and the benefits of marine reserves: Putting Descartes before des horse? Environ. Conserv. 30, 97-103.

Wolfenden J., Cram M., McAuley L., 1998, Marine reserves in New Zealand: Use rights, public attitudes and social impacts. Ocean Coast. Manage. 25, 35-51.

Yamasaki A., Kuwahara A., 1990, Preserved area to effect recovery of overfished Zuwai crab stocks off Kyoto prefecture. Proc. Internat. Symp. King and Tanner Crab, Nov. 1989, Anchorage, Alaska, pp. 575-585.

Yáñez-Arancibia A., Lara-Dominguez A.L., Rojas-Galaviz J.L., Zarate-Lomeli D.J., Villalobos-Zapata G.J., Sánchez-Gil P., 1999, Integrating science and management on coastal marine protected areas in the Southern Gulf of Mexico. Ocean Coast. Manage. 42, 319-344.

Yoklavitch M.M., 1998, Marine harvest refugia for West coast rockfish: A workshop. NMFS Technical Memorandum, SWFSC-255, NOAA.

Zakai D., Chadwick-Furman N.E., 2002, Impacts of intensive recreational diving on reef corals at Eilat, northern Red Sea. Biol. Conserv. 105, 179-187.

Zeller D.C., Russ G.R., 1998, Marine reserves: Patterns of adult movement of the coral trout (Plectropomus leopardus (Serranidae)). Can. J. Fish. Aquat. Sci. 55, 917-924.

Zeller D.C., Stoute S.L., Russ G.R., 2003, Movements of reef fishes accross marine reserve boundaries: Effects of manipulating a density gradient. Mar. Ecol. Prog. Ser. 254, 269-280. 